Historic, Archive Document

Do not assume content reflects current scientific knowledge, policies, or practices. 



\section{WHAT TO PLANT}
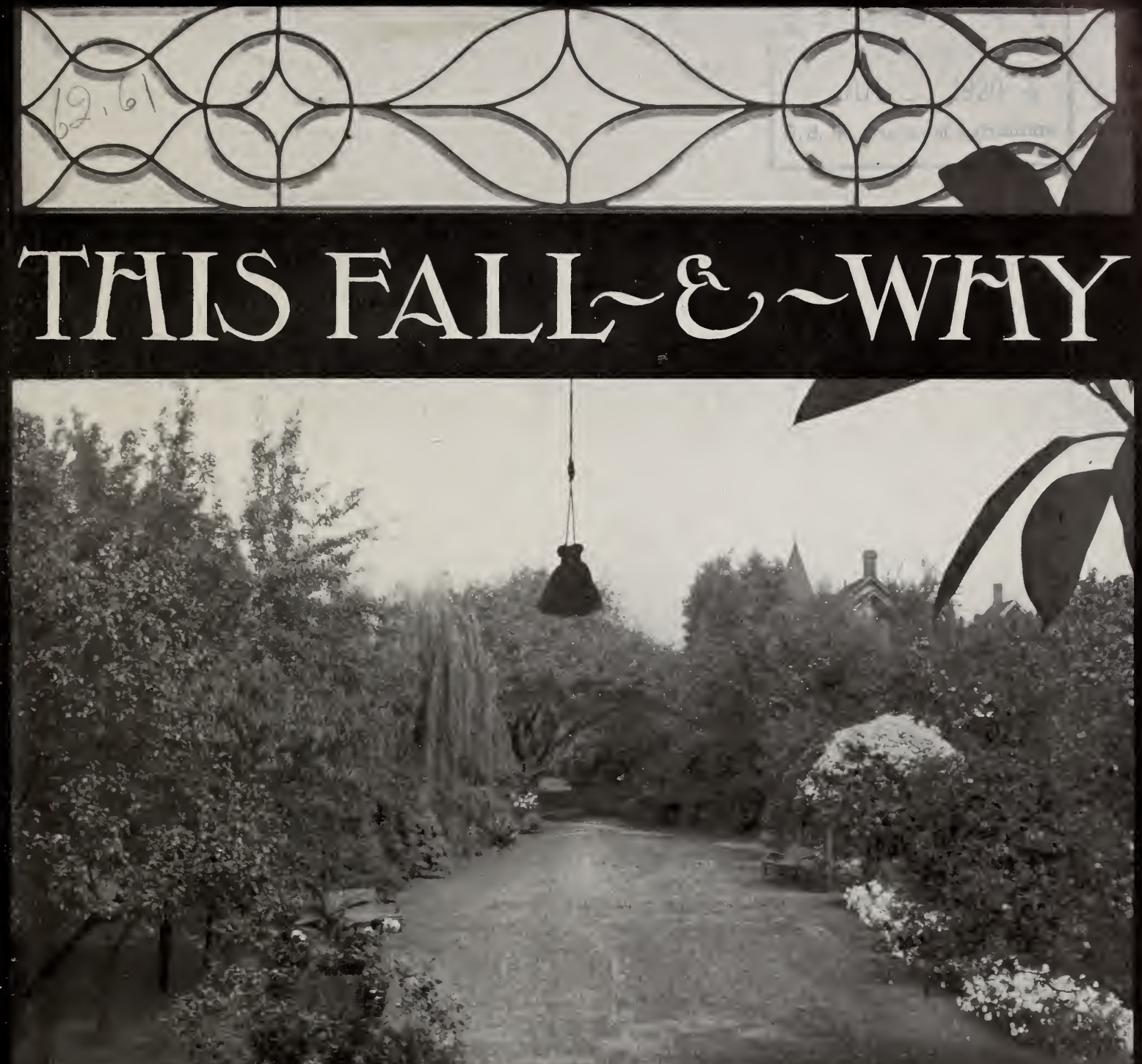

HICKS NURSERIES

WESTBURY,L.I.

1912 


\section{Fall Planting is Best for Most Trees, Shrubs, and Hardy Flowers}

$\mathrm{T}$

HERE are varieties such as Golden Bell, Upright Honeysuckle, Paeonia, etc., which respond to the first touch of spring, and which bloom unsatisfactorily the first summer, if planted after they have started. Fall planting gives the best possible results in foliage and flower.

The possibility of damage from fall planting is far outweighed by a more vigorous growth in May. Fall planting benefits the plant because the roots get started earlier. It benefits your landscape; relieves the rush of work for your gardener and his men; enables the nurseryman to give the plants better attention, delivering them more promptly in cool, moist weather (instead of the more hot, dry weather of April and in early May.) All this is avoided by fall planting. In the fall you get a fuller list of varieties, and you get first selection.

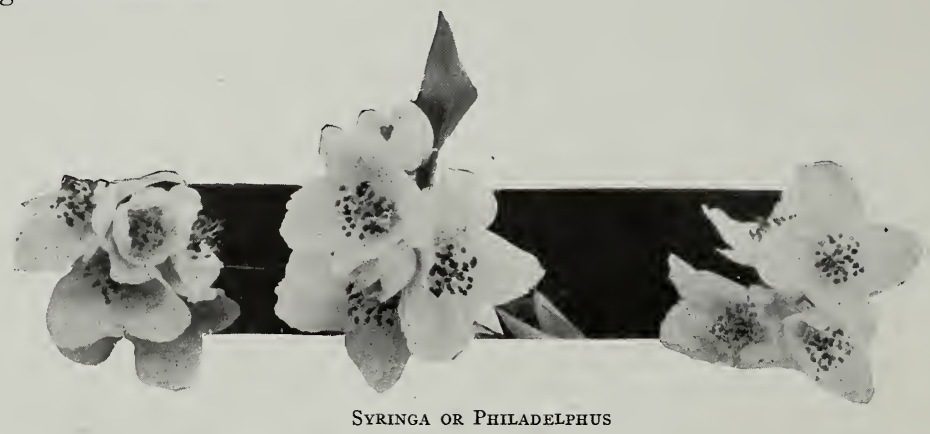

It is doing now what you lack time to do next spring. To those maintaining country homes, no season could be more timely. Personal selection and arrangement is possible now, and is most satisfactory, but in the spring may be inconvenient as the premises are frequently not occupied until a date later than the beginning of the planting season in early March.

Let a visit to our nurseries be one of the important items on your fall programme. During October, nature dons her fall robes and the splendor of the Dogwood, Liquidambar, Oak, etc., will leave pleasant memories. You can always see enough to make a visit worth while.

Varieties more suited for spring can be labelled now and reserved, and delivered before the height and rush of the spring season.

Those usually omitted from fall planting lists are: Beech, Birch, Liquidambar, Magnolia, Althea, Azalea, Japanese Maple.

See 1912 Price List for complete list of stock in all sizes. Have you one of our descriptive catalogues on file for reference and our evergreen editions?

BUSINESS TERMS. See Price list 1912.

PRICES. The prices in this list are for stock loaded at our Nurseries. Five, 50, 500, plants at the 10 , 100 , and 1000 rates.

TERMS: Net Cash. WE CHARGE POR DELIVERY AND PACKING FOR SHIPIIENT.

\section{Isaac Hicks \& Son Westbury, Nassau County, Long Island Telephone, 68 Westbury}




\section{Deciduous Trees}

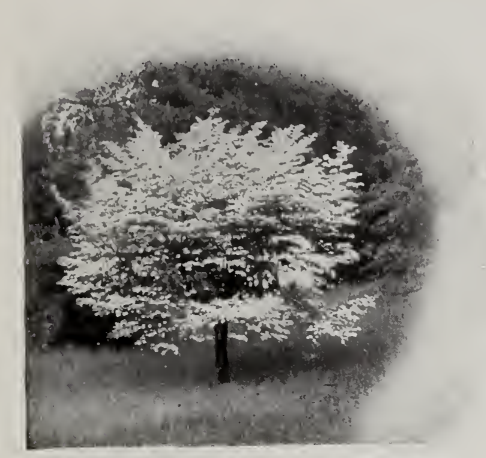

Flowering Dogwood. One of the most conspicuous elements in nature's May composition. Red berries succeed the flowers and the crimson foliage in October is a most fitin groups of trees and among shrubs.

\section{Elm, American. Ulmus Americana.}

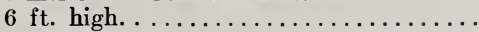

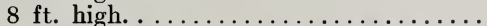
$10-14 \mathrm{ft}$. high, $1 \frac{1}{2}$ in. diam., $3-5 \mathrm{ft}$. spr.... 10-14 ft. high, 2 in. diam., 4-7 ft. spr. ...

Horse-Chestnut. Aesculus hippocastanum.

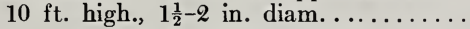

\section{$200 \quad 1750$}

Linden, Silver. Tilia tomentosa, syn., T. Argentea; syn., T. alba.

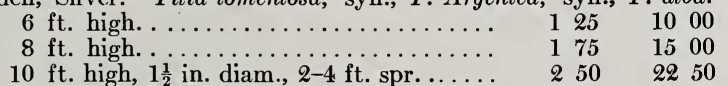
10-12 ft. high, 2 in. diam., $2-4$ ft. spr. 8 yrs. $450 \quad 4000$

Linden, Small-leaf. Tilia ulmifolia, syn. microphylla. $8 \mathrm{ft}$. high. ................ $150 \quad 1250$

Linden, American. Tilia Americana. $8 \mathrm{ft}$. high. ................. $100 \quad 800$ $10-14 \mathrm{ft}$. high, 2 in. diam., $4-6 \mathrm{ft}$. spr. ..... $200 \quad 1750$

Maple, Norway. Acer platanoides.

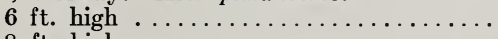
$8 \mathrm{ft}$. high. . . . . . .
$10 \mathrm{ft}$. high, $1 \frac{1}{4}$ in. diam. $\ldots \ldots \ldots \ldots \ldots \ldots$ $10-14 \mathrm{ft}$. high, $1 \frac{1}{2}$ in. diam., $3-5 \mathrm{ft}$. spr., 9 yrs..
$12-16 \mathrm{ft}$. high, 2 in. diam., $4-6 \mathrm{ft}$. spr., 10 yrs. 14-18 ft. high, $2 \frac{1}{2}$ in. diam., $4-6 \mathrm{ft}$. spr. ......

$\begin{array}{rrrr} & 60 & 5 & 00 \\ 1 & 00 & 9 & 00 \\ 1 & 25 & 11 & 00 \\ 2 & 25 & 20 & 00 \\ 3 & 00 & 25 & 00 \\ 4 & 50 & 40 & 00\end{array}$

15000

Maple, Silver. Acer dasycarpum.

A quick growing tree. Our stock is of excellent quality with straight single leaders, and broad tops, offered at a low price. If the ground is well manured, they will make better screens than Lombardy Poplars, which are frequently asked for.

$8 \mathrm{ft}$, high

10-16 ft high, $1 \frac{1}{2}$ in. diam., $3-6$ ft. spr......... 125

10-16 ft. high, $2-2 \frac{1}{2}$ in. diam., 4-7 ft. spr. ... 150

600

1000

6000

Maple, Sugar (Rock or Hard). Acer saccharum; syn., A. saccharinum. $8-10$ ft. high. ............... 150 12 50 $10-14 \mathrm{ft}$. high, $1 \frac{1}{2}$ in. diam., $5-7 \mathrm{ft}$. spr....... $250 \quad 2250$

Maple, Red or Scarlet. Acer Rubrum.
5 ft. high.

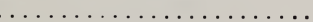

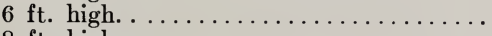
8 ft. high. .
$\begin{array}{rrrr} & 40 & 3 & 00 \\ & 50 & 4 & 00 \\ 1 & 25 & 11 & 00 \\ 2 & 00 & 17 & 50\end{array}$
10-14 ft. high, $1 \frac{1}{2}$ in. diam., $4 \mathrm{ft}$. spr. ...... 200
2500 3500 10000

12-18 ft. high, $2 \frac{1}{2}$ in. diam., $4-8 \mathrm{ft}$. spr. .... $5550 \quad 5000$

$\begin{array}{rrrrr}\text { Each } & \text { Per } 10 & \text { Per } 100 \\ & 75 & 6 & 00 & 3000 \\ 1 & 00 & 8 & 50 & 5000 \\ 1 & 50 & 12 & 50 & 7500 \\ 2 & 50 & 20 & 00 & \end{array}$

These are vigorous little trees suitnd Spruce.

\begin{tabular}{|c|c|c|}
\hline Each & Per 10 & Per 100 \\
\hline$\$ 25$ & $\$ 200$ & $\$ 1800$ \\
\hline 40 & 350 & \\
\hline 100 & 750 & $\begin{array}{lll}60 & 00\end{array}$ \\
\hline
\end{tabular}

6000

\section{$\begin{array}{lll}60 & 5 & 00\end{array}$}

$150 \quad 1200$

\section{$\begin{array}{llll}125 & 10 & 00\end{array}$} 200

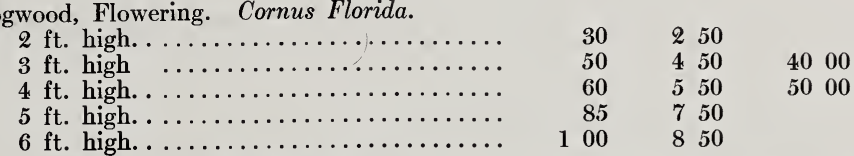

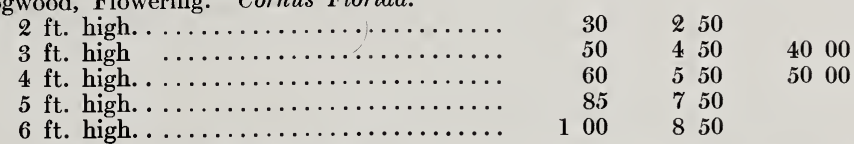

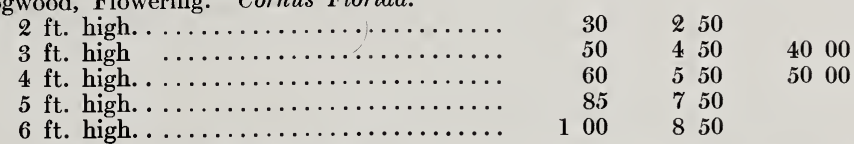

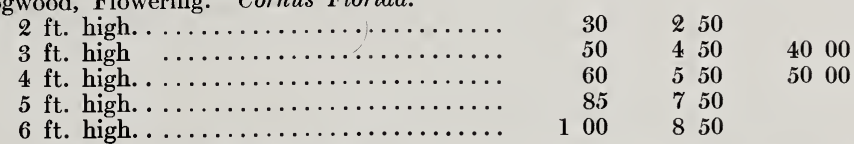

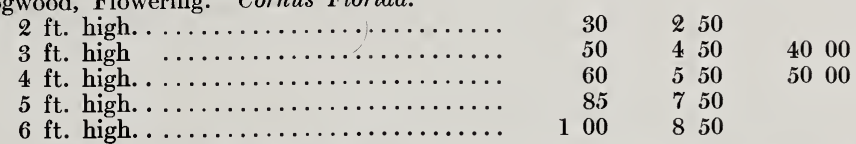

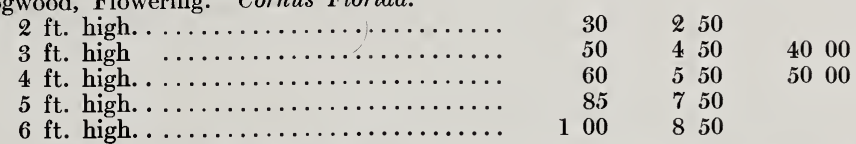




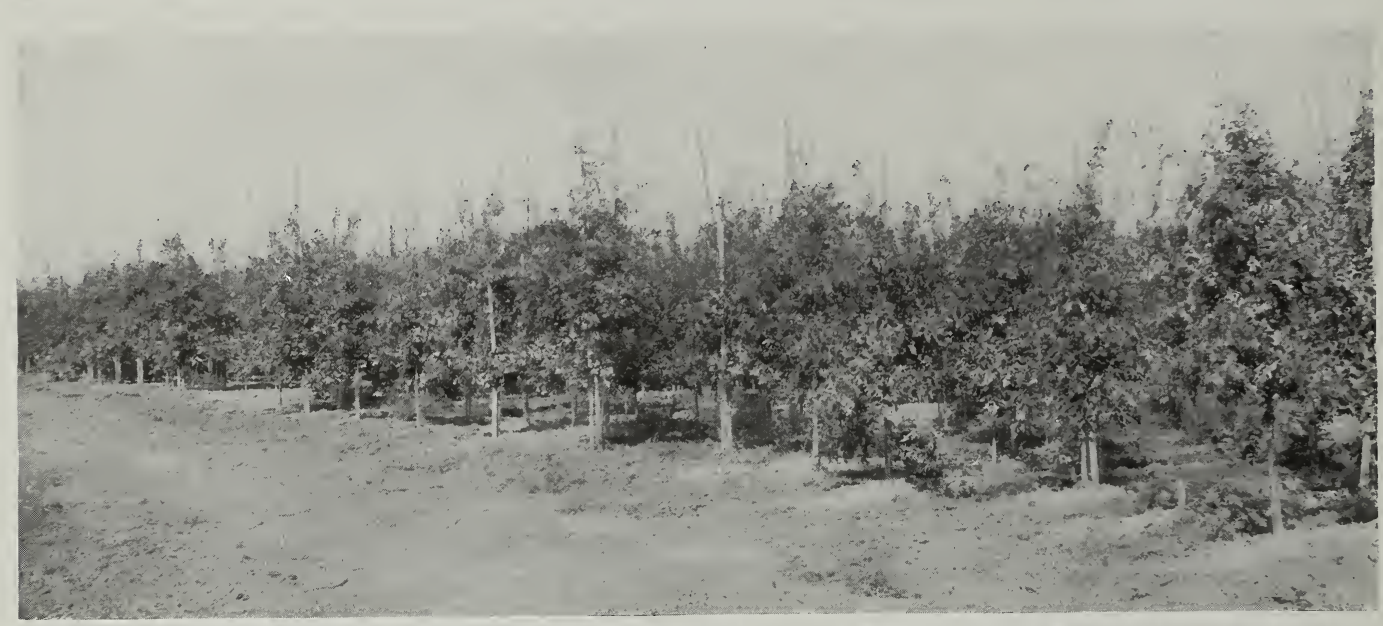

PIN OAK. A growing demand, and a good stock of straight, well-branched, root-pruned trees, sure to grow and please, tells our whole story. They are especially effective planted at intervals in shrubbery. They are trained up to bamboo poles to insure a straight trunk.

\section{DECIDUOUS TREES - Continued}

Oak, Pin. Quercus palustris.

$6 \mathrm{ft}$. high.

$8 \mathrm{ft}$. high.

10-14 ft. high, 2 in. diam., 4-7 ft. spr. .......
10-14 ft. high, $1 \frac{1}{2}$ in. diam., $3-6 \mathrm{ft}$. spr.

\begin{tabular}{|c|c|c|}
\hline Each & Per 10 & Per 100 \\
\hline$\$ 100$ & $\$ 900$ & $\$ 7500$ \\
\hline 125 & 1000 & \\
\hline 225 & 2000 & \\
\hline 350 & 3250 & \\
\hline
\end{tabular}

Poplar, Carolina. Populus deltoides, var. Carolinensis. $8 \mathrm{ft}$. high. . . . . . . . . . 40 $10 \mathrm{ft}$. high, $1 \frac{1}{2}$ in. diam., $3-4 \mathrm{ft}$. spr. . . . . . $\quad 60$

350

500

4000

Poplar, Japanese. Populus suaveolens.
$8 \mathrm{ft}$. high.
100
750
$10 \mathrm{ft}$. high, $1 \frac{1}{2}$ in. diam.
125
1500
$10-14 \mathrm{ft}$. high, 2 in. diam., $3-6 \mathrm{ft}$. spr. ....
225
2000

Poplar, Lombardy. Populus nigra, var., Italica, syn., P. fastigiata. $8 \mathrm{ft}$. high. ................. $40 \quad 350$ $10 \mathrm{ft}$. high, $1 \frac{1}{4}-1 \frac{1}{2}$ in. diam., $3-4$ ft. spr. ...... $\quad 60 \quad 500$

3000 4000

Poplar, Balsam. Populus Balsamifera.

$6 \mathrm{ft}$. high. $\ldots \ldots \ldots \ldots \ldots \ldots \ldots \ldots \ldots$
$10-16$ ft. high. $2-3$ in. $\operatorname{diam} \ldots \ldots \ldots \ldots \ldots$
25

Willow, Salamon's Weeping. Salix Babylonica, var., Salamonii. $6 \mathrm{ft}$. high...................... $40 \quad 300$

Willow, Golden-barked. Salix vitellina aurea (pendula) 2-4 ft. high. . . . . . . . . . . . . . . . . $2-4 \mathrm{ft}$. high. $\ldots \ldots \ldots \ldots \ldots \ldots \ldots \ldots \ldots \ldots \ldots \ldots \ldots \ldots \ldots \ldots \ldots \ldots \ldots \ldots \ldots$
$5-6 \mathrm{ft}$. high. $\ldots \ldots \ldots \ldots \ldots$ 10-14 ft. high, $1 \frac{1}{2}-2 \frac{1}{2}$ in. diam., $6-8 \mathrm{ft}$. spr. ... 100

$\begin{array}{ll}1 & 20 \\ 4 & 00\end{array}$

$\begin{array}{ll}4 & 00 \\ 9 & 00\end{array}$

1000 3500

Wiilow, Laurel-leaf. Salix pentandra.

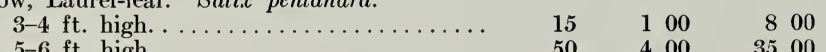

For Larger Trees see Price list 1912. It lists trees fifteen to twentyfive years old, which save you ten to twenty years as compared with usual sizes sold by nurseries. Our blocks of these trees look like an orchard, the trees spreading twelve to twenty-five feet. The tops are trained to symmetrical form and are twenty to forty feet high. They are ready for delivery this fall by wagon, tree mover, motor-truck or rail.

There are several thousand for you to select from. Come and see the results you can obtain without waiting.

Our tree moving department can move from your vicinity, trees one and a half feet in diameter, fifty feet high, forty feet spread, or larger.

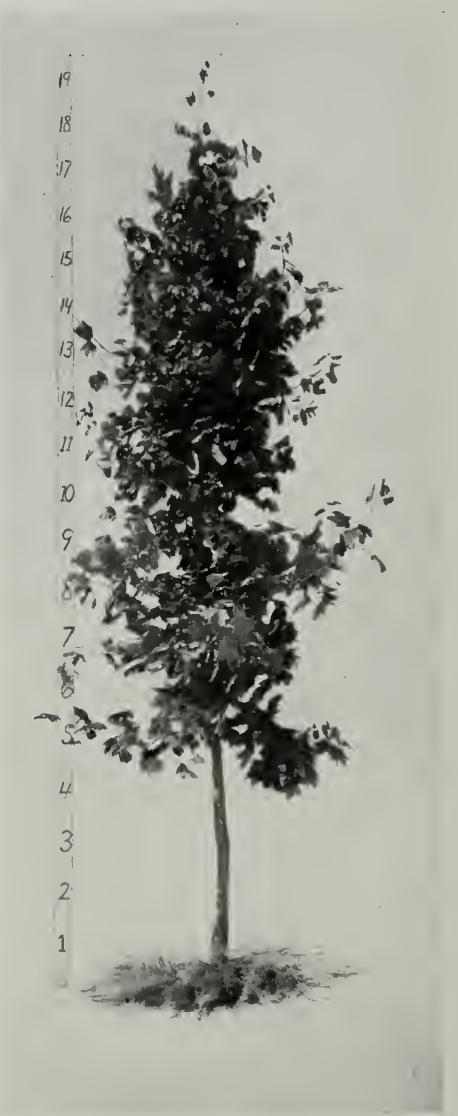

A two and one-half inch Norway Maple, showing straight trunk, numerous branches and fibrous roots. 


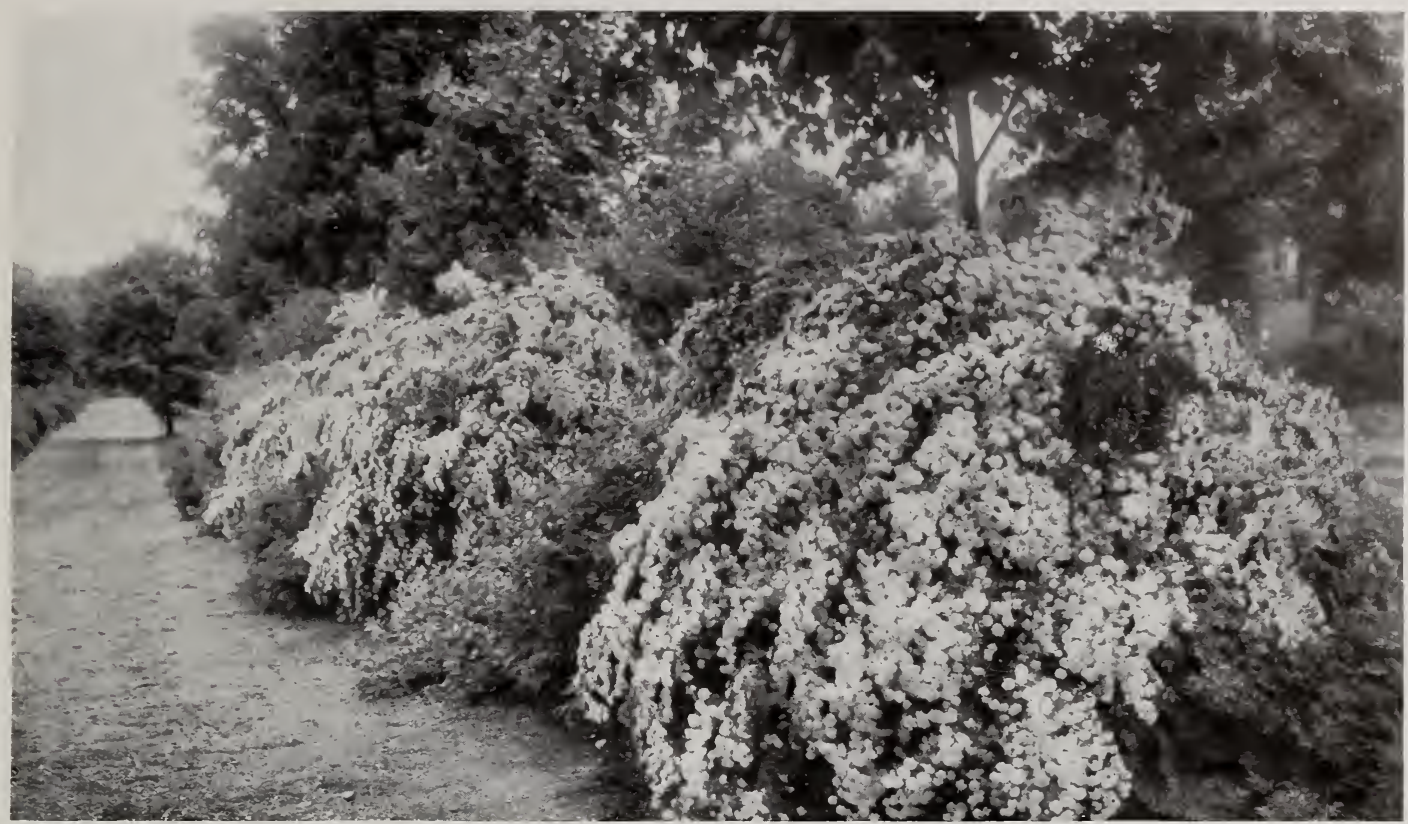

There could hardly be a representative border without some Spirea Van Houtti. In May, the spot is magnetic to the eye. There is graceful outline the whole season.

\section{Deciduous Shrubs}

They are used for concealing unsightly objects, planting in irregular masses along boundaries, edging down a woodland, protecting against dust from the road, making divisions in the landscape, banking by foundations. They are appropriate on large and small places, alike.

You have thought of several solutions for your landscape problems.

Shrubs are pretty sure to enter the solution. Come and see what is most efficient.

Barberry, Japanese. Berberis Thunbergi - excellent for hedges. Plant two feet apart. Each Per $10 \quad$ Per 100

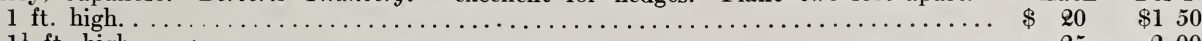

$1 \frac{1}{2} \mathrm{ft}$. high. . . . . . . .

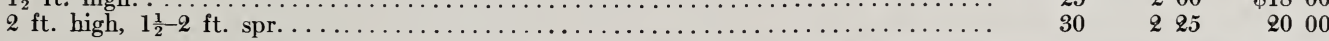

Barberry, Common. Berberis vulgaris. $\quad$ Each Per 10 Per 100

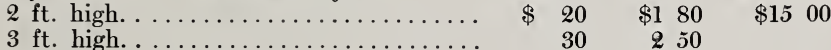

Button Bush. Cephalanthus occidentalis,

A big, broad shrub with glossy dark green foliage.

$1-1 \frac{1}{2} \mathrm{ft}$. high.................... 10

$3 \mathrm{ft}$. high. . . . . 15

90

$4 \mathrm{ft}$. high. . . . . . . . . . . .

20

125

150

Catalpa Bungei, Bush Form. Sheared Domes $2 \mathrm{ft}$. high, $2 \mathrm{ft}$. spr.............. $40 \quad 300$

$3 \mathrm{ft}$. high, $2-3 \mathrm{ft}$. spr........... $50 \quad 400$

Deutzia crenata, flore pleno.

$1-1 \frac{1}{2} \mathrm{ft}$. high. . . . . . . . . . .

$2 \mathrm{ft}$. high. .

$4-5 \mathrm{ft}$. high, $3-4 \mathrm{ft}$. spr............

Deutzia, Pride of Rochester.

$1-1 \frac{1}{2} \mathrm{ft}$. high. . . . . . . . . . .

$2 \mathrm{ft}$. high. . . . . . . . .

$3-4 \mathrm{ft}$. high. . . . . . . . . . . . .

$\begin{array}{ll} & 80 \\ 1 & 25 \\ 1 & 80 \\ 2 & 50\end{array}$

125

180

30

600

1000

1500

2000

$\begin{array}{rrrrr} & 80 & 6 & 00 \\ 1 & 20 & & 10 & 00 \\ 2 & 00 & & 15 & 00\end{array}$

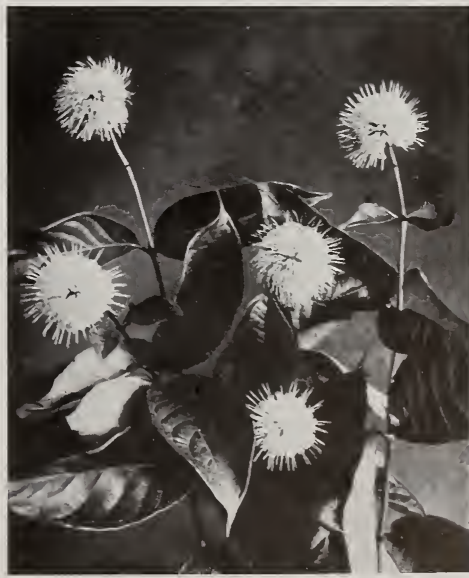

Butron Bush. The interesting pendent balls appear in July when there is such a dearth of bloom. We recommend it to those wishing a large mass of good foliage at a low cost. 


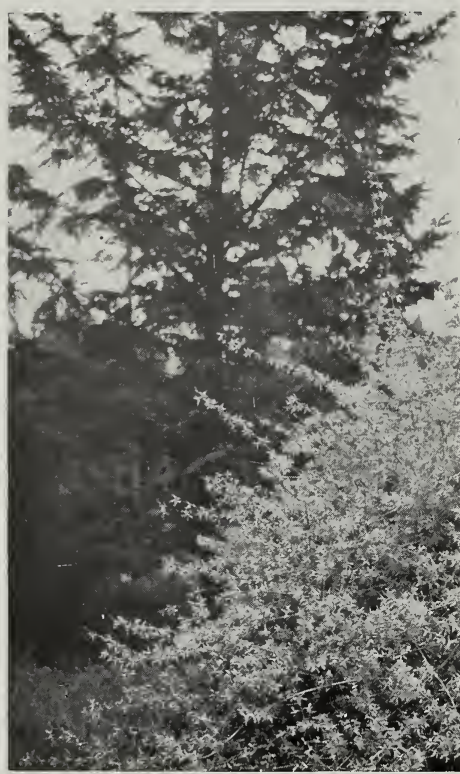

Forsythia, may be always showy, but especially illuminating with an evergreen background. Evergreens also make fitting frames for Magnolias, White Birch and perennial plants.

\section{DECIDUOUS SHRUBS - Continued}

Dogwood, Red-twigged. Cornus alba, var., Siberica.

A shrub that you get full value from right away. The bright carmine red twigs are cheerful all winter. In summer it is a vigorous broad shrub with white flowers in June and white berries in August

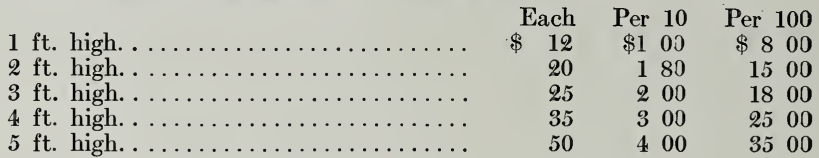

Dogwood, Yellow-twigged. Cornus stolonifera, var., lutea.

$$
1 \frac{1}{2} \mathrm{ft} \text {. high. . . . . } \ldots \ldots \ldots \ldots \ldots \ldots \ldots, \quad 2_{20} \quad 180 \quad 1500
$$

Fringe, White. Chionanthus Virginica.

You will be glad to make the acquaintance of this plant. It grows ten or fifteen feet high and has big, dark leaves like an India rubber tree. In June, it is hung with a lace-like white fringe.
$2 \mathrm{ft}$. high. . . . . . . . . . . . . . .
$40 \quad 3 \quad 50$
3000
$3 \mathrm{ft}$. high........................ $60 \quad 500$

Golden Bell. Forsythia suspensa and Viridissima.

The Golden Bells bloom about April fifteenth. Plant in the fall or early in the spring, and you get a mass of bright flowers
$1 \mathrm{ft}$. high. . . . . . . . . . . . . . .
$\begin{array}{rrrr}10 & 70 & 600\end{array}$
$2 \mathrm{ft}$. high. . . . . . . . . . . . . .
$\begin{array}{llll}120 & 10 & 00\end{array}$
$3 \mathrm{ft}$ high. . . . . . . . . . . . . . .
$4 \mathrm{ft}$ high. . . . . . .
200
1800
$5 \mathrm{ft}$. high. $\ldots \ldots \ldots \ldots \ldots \ldots \ldots \ldots \ldots \ldots$
$6 \mathrm{ft}$. high. . . . . . . . .
300
2000
2500

$\begin{array}{lllll}40 & 3 & 50 & 25 & 00 \\ 50 & 4 & 00 & 30 & 00\end{array}$

Hazelnut, American. Corylus, Americana.

The Hazelnut gives abundant crops. We offer broad bushes that have been bearing for the past two years.

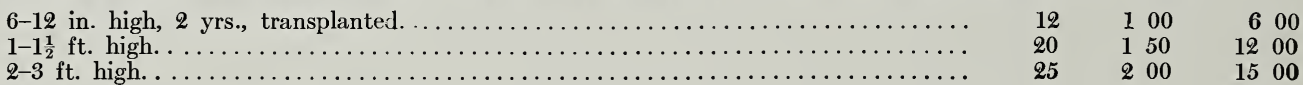

Honeysuckle, Upright. Lonicera Tatarica. of April.

Sturdy shrubs with oak-like branches. Fall planting is especially valuable because they start with lilacs, the middle

$1 \mathrm{ft}$. high.

2 ft. high. . . .

$4 \mathrm{ft}$. high, 3-4 ft. spr. . . . . . . . . .

$5 \mathrm{ft}$. high, 3-4 ft. spr.

$6 \mathrm{ft}$ high, $4-6 \mathrm{ft}$. spr $\ldots \cdots \cdots \cdots \cdots \cdots$

Honeysuckle, Bush. Lonicera Morrowi.

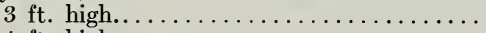

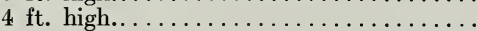

Honeysuckle, Fragrant. Lonicera Fragrantissima.

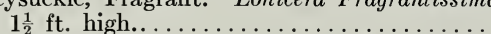

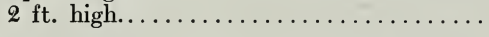

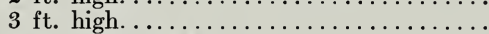

\begin{tabular}{|c|c|c|}
\hline Each & Per 10 & Per 10 \\
\hline $\begin{array}{ll}\frac{7}{8} & 18\end{array}$ & $\$ 150$ & $\$ 12$ \\
\hline 20 & 180 & 15 \\
\hline 25 & 200 & 18 \\
\hline 35 & 250 & \\
\hline 50 & $\begin{array}{l}400 \\
4\end{array}$ & 3 \\
\hline 75 & 600 & 50 \\
\hline
\end{tabular}

$35 \quad 300$

$40 \quad 350$

2500 3000

$20 \quad 150$

1200

\section{0}

1800

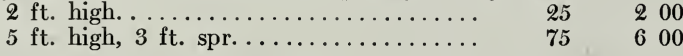

Hydrangea, Paniculata grandiflora.
2 ft. high.

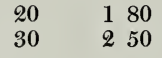
1500
3 ft. high. . . . .
2000

Hydrangea, Paniculata, var., Tardiva. Late flowering type.
$3 \mathrm{ft}$. high.
30
250
2000

Hydrangea, Paniculata var., praecox, syn., acuminata. Early flowering type. $2 \mathrm{ft}$. high. .................... $30 \quad 250$

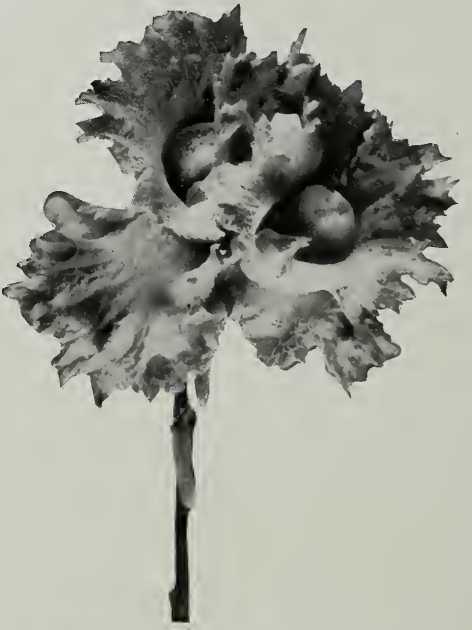

HAZELNUT. This adapts itself to dry ground conditions. Its fruiting qualities need no introduction. Used as a cover plant under trees it
holds moisture, leaf mould and the trees grow much faster. 


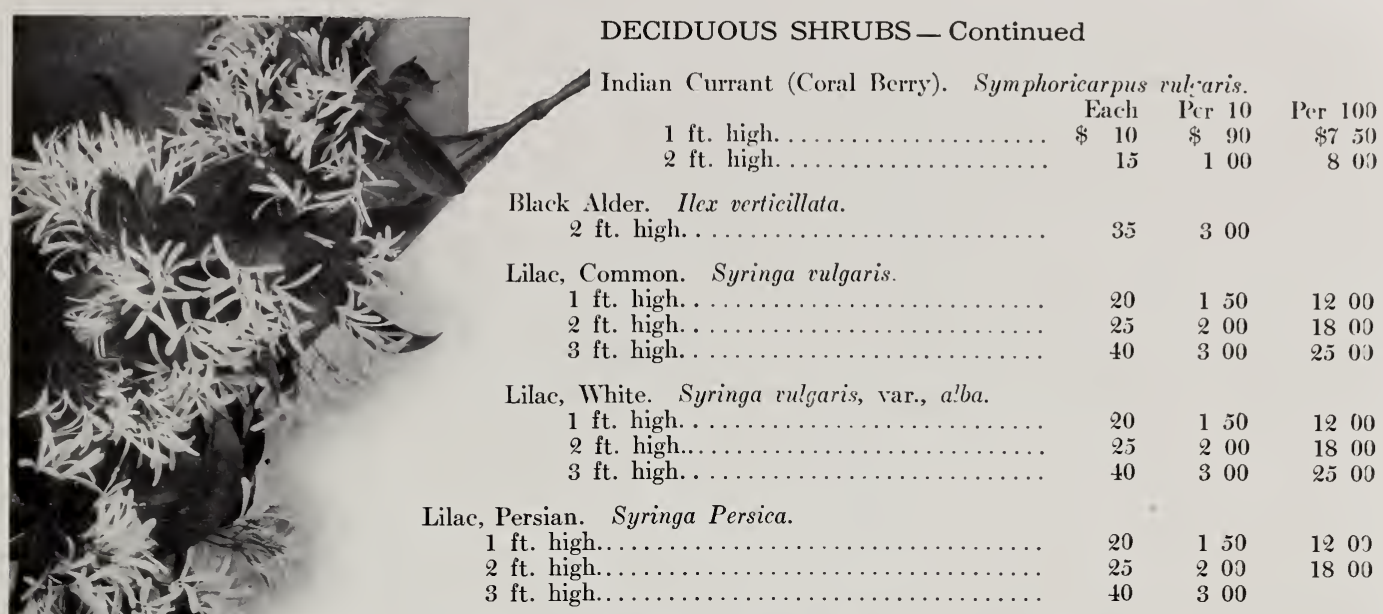

Pearl Bush. Exochorda grandiflora.

A mass of white in early May, just ahead of the familiar display of Spirea Van Houtti. This and Persian Lilac bloom simultaneously and constitute a combination rarely seen or excelled. It is apt to be thin at the base, which can be remedied by planting Barberry in front.

\begin{tabular}{|c|c|c|c|}
\hline $\begin{array}{l}1 \mathrm{ft} . \text { high. } \\
1^{1} \frac{1}{2}-2 \mathrm{ft} \text {. high. } \\
\ldots\end{array}$ & $\begin{array}{l}25 \\
40\end{array}$ & $\begin{array}{ll}2 & 00 \\
3 & 50\end{array}$ & $\begin{array}{ll}18 & 09 \\
30 & 00\end{array}$ \\
\hline $\begin{array}{l}\text { t, California. Ligustrum oralfolinm. } \\
2 \text { in. high., } 1 \text { yr. cuttings }(\$ 15 \text { per } 1030) \text {. }\end{array}$ & & & \\
\hline $1 \mathrm{ft}$. high $(\$ 25$ per 1000$) \ldots \ldots \ldots \ldots$ & 05 & $\begin{array}{l}30 \\
40\end{array}$ & 3 \\
\hline $2 \mathrm{ft}$. high $(\$ 40$ per 1000$)$. & 06 & $\tilde{50}$ & \\
\hline $3 \mathrm{ft}$. high. $(\$ 55$ per 1000$) \ldots \ldots \ldots$ & 08 & 70 & 6 \\
\hline
\end{tabular}

Privet Ibota. Standard or Bay Tree Form.

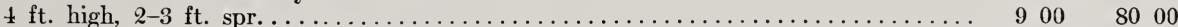

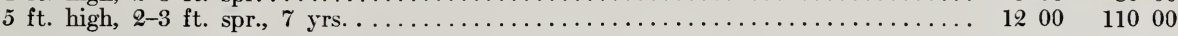

Privet, Ibota. Ligustrum Ibota.
$1 \mathrm{ft}$. high.
等
$3 \mathrm{ft}$. high.

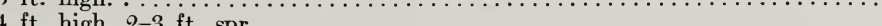
30
800
1000

Cut back severa 1 times, $7 \mathrm{yrs}$. old; plants about as wide as high.

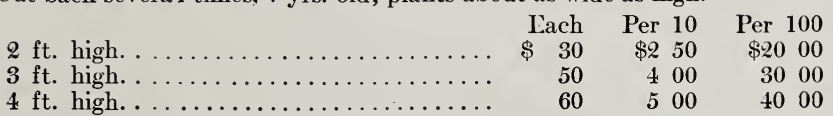

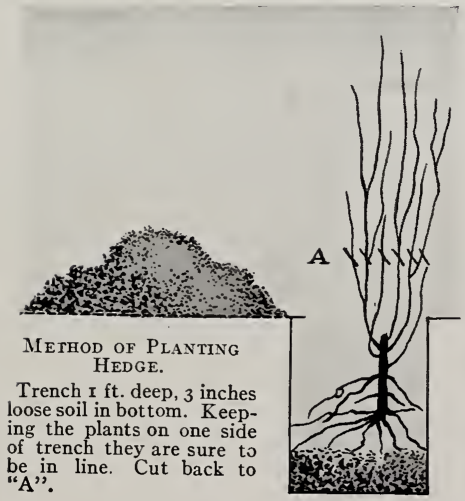

In reference to boundary plantings your choice is not limited to privet. Let us mention as a superior treatment, a belt or group of flowering shrubs. Excellent compositions can be made with Japanese Barberry, RedTwig Dogwood, Golden Bell, Upright Honeysuckle, Silver Thorn, Spirea Thunbergii, Spirea Van Houtii, Syringa, Viburnum, Weigelia, Witch Hazel, and Indian Currant. Another type of boundary planting might consist of low-branched trees, such as Linden, Dogwood, Pin Oak, Beech, Birch, Liquidambar, Chinese Cork Tree, Larch, Pines, and Hemlocks. These can be planted ten to twenty feet apart in an irregular line from one to three trees wide, with or without shrubs between.

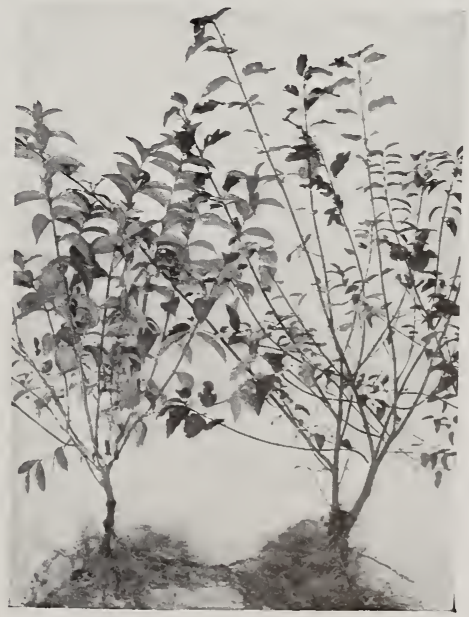

Specimen of two year shrub, from cutting. Thrifty and vigorous. Effective results are only one year off, when such stock is utilized. 


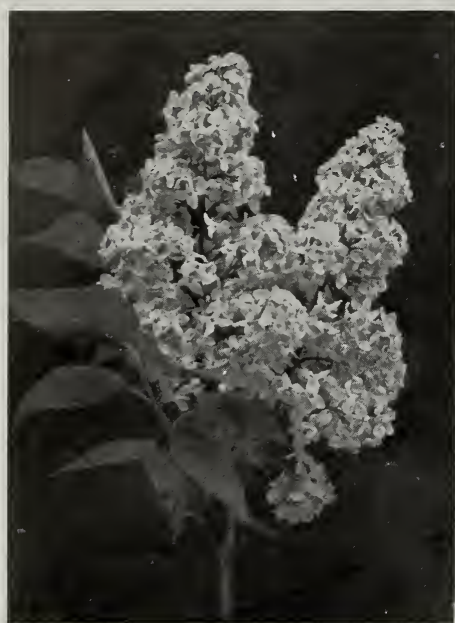

Lilac. These give May a reputation that Roses give June. Foliage frequently mildews, and the plants are usually thin at the base. Hence they are better used among other shrubs, without these failings.

\section{DECIDUOUS SHRUBS - Continued}

Privet Ibota, Pyramidal.

$4 \mathrm{ft}$. high, $2-3 \mathrm{ft}$. spr.

Each

500

$6 \mathrm{ft}$. high, $2 \frac{1}{2}-4 \mathrm{ft}$. spr. . . . . . . . .

600

Per 10 $\$ 2000$

4500

Privet Ibota, Dome Shape.
$2 \mathrm{ft}$. high. .
200
1500
300

$3 \mathrm{ft}$. high.

2500

Arches of California Privet; Foliage within $2 \mathrm{ft}$. of centre with double iron frame.
$7 \mathrm{ft}$. high, $6 \mathrm{ft}$. spr.
$1400 \quad 120 \quad 00$

Rhodotypus Kerrioides.

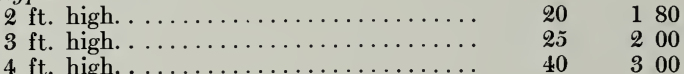

Shad Bush. Amelanchier Canadensis.

$2 \mathrm{ft}$. high. ................... $35 \quad 300 \quad \$ 2500$

Silver Thorn. Eleagnus umbellata.

An excellent shrub for dry, sterile soils. Further praise is unnecessary as far as many Long Island planters are concerned. The foliage is silvery green and the red berries attract the birds all winter.

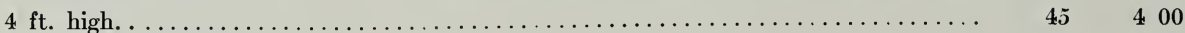

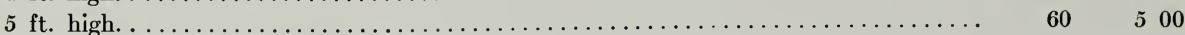

Snowberry. Symphoricarpus racemosus.

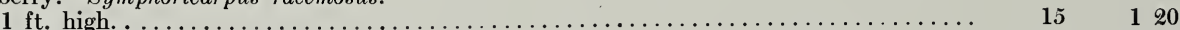

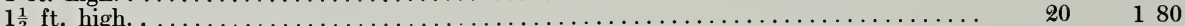

$2 \mathrm{ft}$. high.

$3 \mathrm{ft}$ high, $2-3 \mathrm{ft}$ spr.

250

Siberian Pea Tree. Caragana arborescens.

$4 \mathrm{ft}$. high, $3 \mathrm{ft}$. spr

$5 \mathrm{ft}$. high, $3 \mathrm{ft}$. spr.

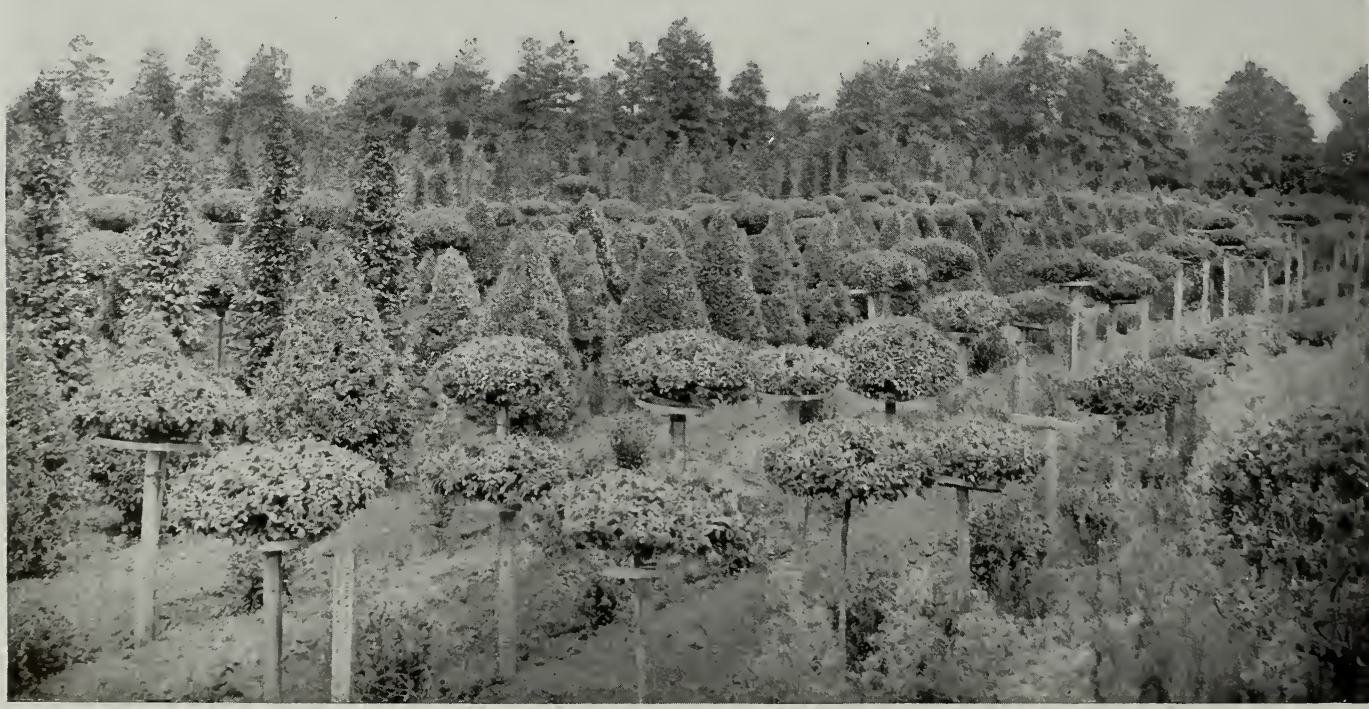

Our block of trained Privet, Standard or Bay Tree form, with straight stems and round heads, and the Pyramidal trained in conical shape. These are especially valuable as they do not demand winter storage like the Bay and do not require protection like the Box. We have been eight years training these, and regard them invaluable for formal gardens. We also offer Privet Arches for arching paths. 


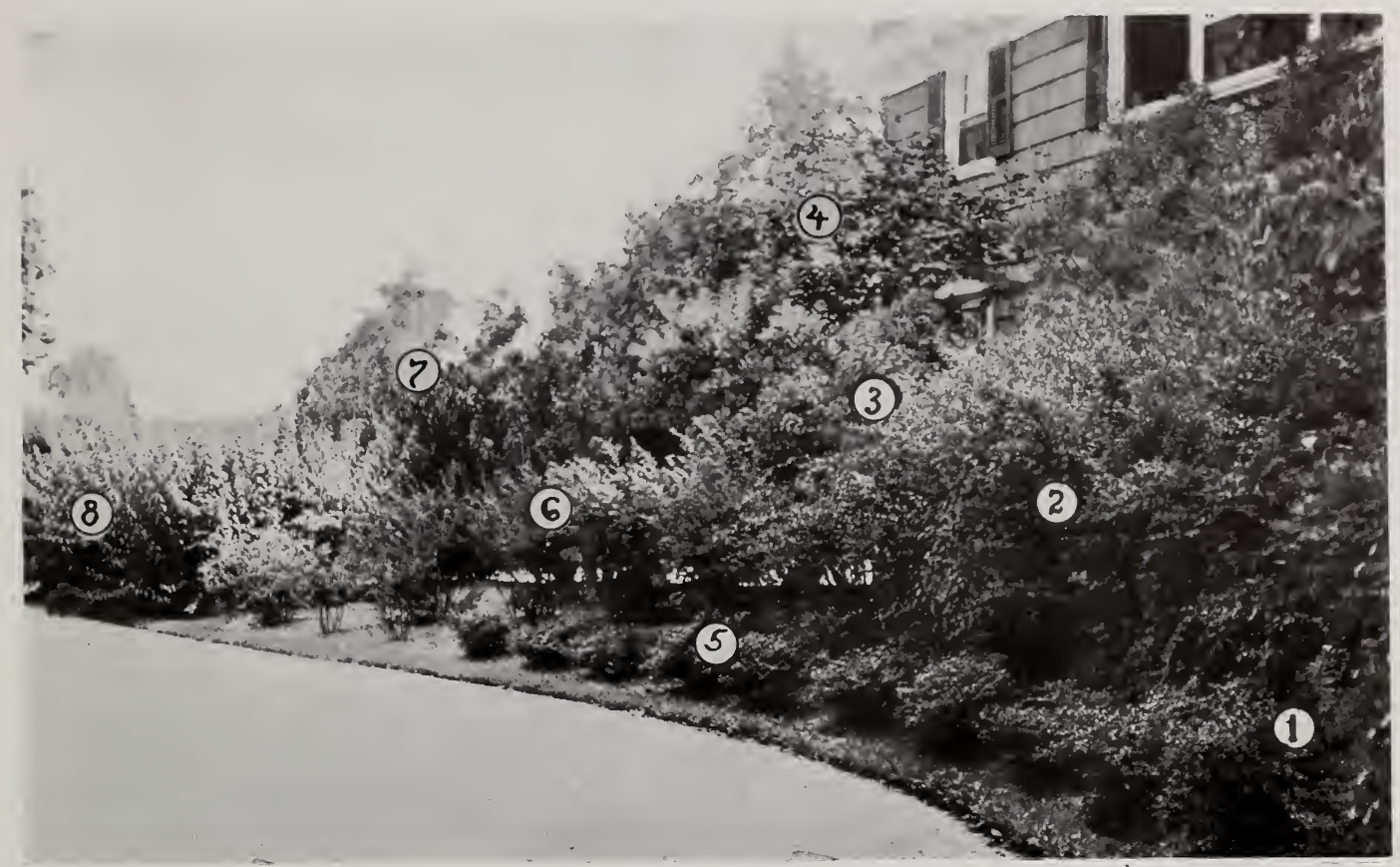

An everyday problem is here illustrated. Service drive, kıtchen windows and drying yard, effectively and ecunomically eliminated from the landscape and invisible trom the entrance court. No. I Stephanandra; No. 2 Rhodotypus: No. 3 Purple Fringe (Preferably Upright Honeysuckle); No. 4 Norway Maple; No. 5 Barberry; No. 6 Spirea Van Houtti (recently thinned out); No. 7 Privet; No. 8 Forsythia.

\section{DECIDUOUS SHRUBS - Continued}

Spirea, Thunberg's. Spirea Thunbergii.

$1 \mathrm{ft}$. high. . ........................

$1 \frac{1}{2} \mathrm{ft}$. high.

$\begin{array}{rrr}\text { Each } & \text { Per } 10 \\ \$ \quad 20 & \$ 180 \\ 25 & 200\end{array}$

Spirea Bridal Wreath. Spirea prunifolia, var., flore pleno.

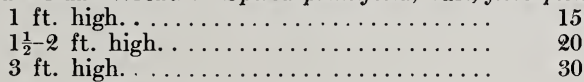

$4 \mathrm{ft}$. high. . . . $\ldots \ldots \ldots \ldots \ldots \ldots \ldots \ldots \ldots, \quad 35$

Spirea Van Houtii.
$1 \frac{1}{2} \mathrm{ft}$. high.
$2 \mathrm{ft}$. high

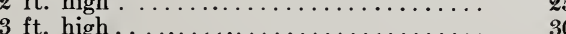

Spirea opulifolia.

$$
5 \mathrm{ft} \text {. high... }
$$

Spirea Anthony Waterer. Spirea Bumalda.

$1-1 \frac{1}{2} \mathrm{ft}$. high $\ldots \ldots \ldots \ldots \ldots \ldots \ldots \ldots \ldots \ldots \ldots$
$2 \mathrm{ft}$. high.$\ldots \ldots \ldots \ldots \ldots \ldots \ldots \ldots$

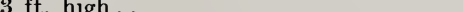

Sumach, Shining. Rhus copalina.

3-4 ft. high . . . . . . . . . . . . . . . . 30

Sumach, Smooth. Rhus glabra. $3-4 \mathrm{ft}$. high . . . . . . . . . . . . .

Sumach, Fragrant. Rhus aromatica. $2 \mathrm{ft}$. high................... $30 \quad 250$

Sweet-scented Shrub. Calycanthus floridus.

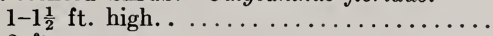

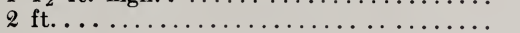

5
0
0

$\begin{array}{ll}1 & 00 \\ 1 & 80 \\ 2 & 50\end{array}$

120

200

Per 100

$\$ 1500$

1800

$\begin{array}{rr}8 & 00 \\ 15 & 00 \\ 20 & 00 \\ 25 & 00\end{array}$

$300 \quad 2500$

1000

1800

2000

$250 \quad 2000$

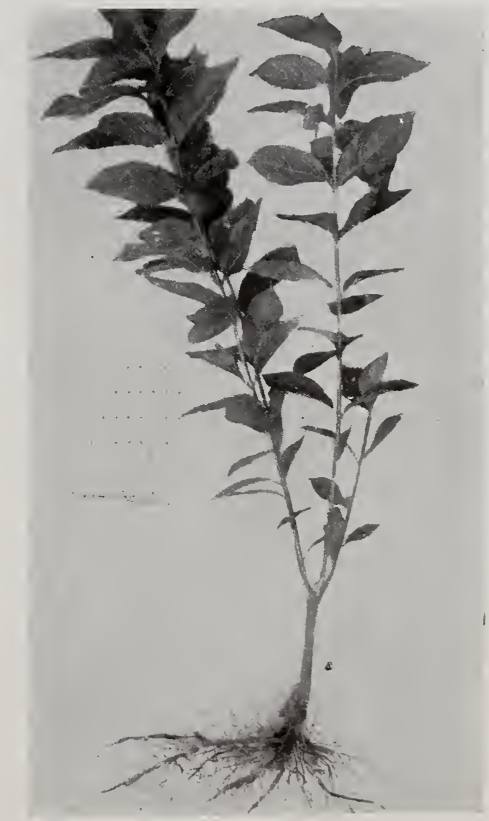

Specimen of one year shrub from cutting. These are decidely economical. We offer such in

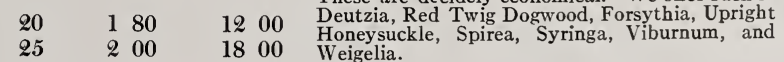




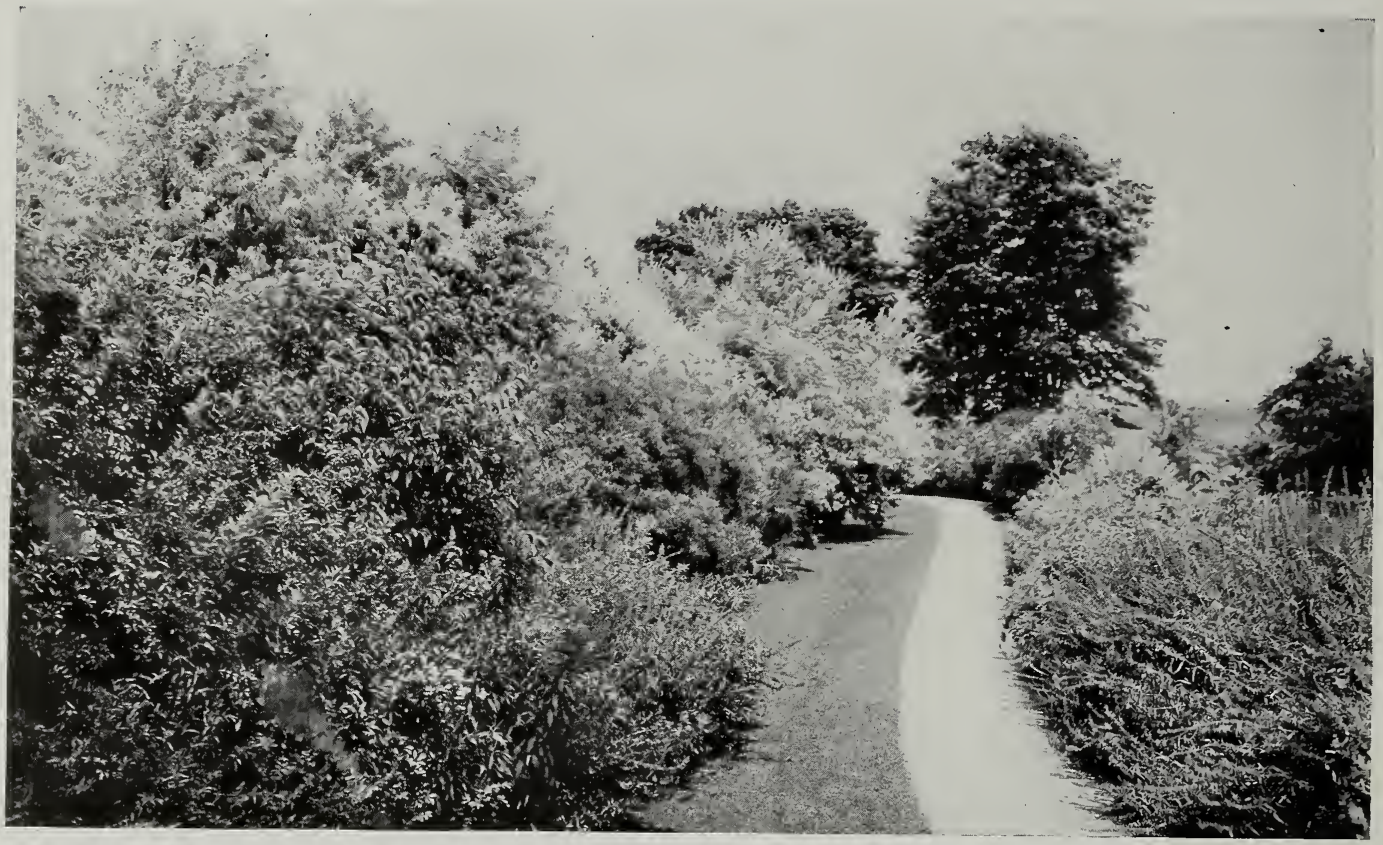

A path is infinitely more attractive if interrupted with shrubs, unfolding secrets at every angle. Unsightly objects are simultaneously hidden and privacy sustained. We have shrubs that will give this effect quickly. See Upright Honeysuckle, Buttonbush, Deutzia, Privet, Lilac, Syringa,

\section{DECIDUOUS SHRUBS - Continued}

Sweet Pepper Bush. Clethra almifolia. Spikes of white flowers in July.

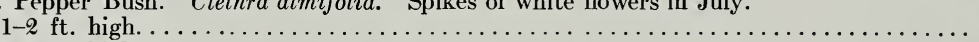

2-3 ft. high.

Fach Per 10

$\$ 20 \$ 150$

Per 100

Syringa (Mock Orange). Philadelphus coronarius.

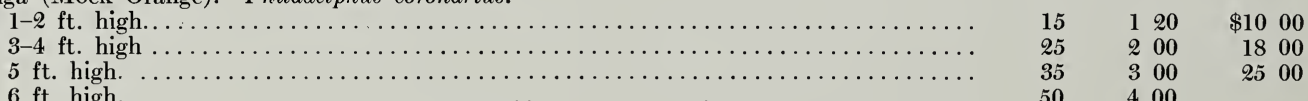

Syringa, Philadelphus grandiflorus. Pure white flowers in June.

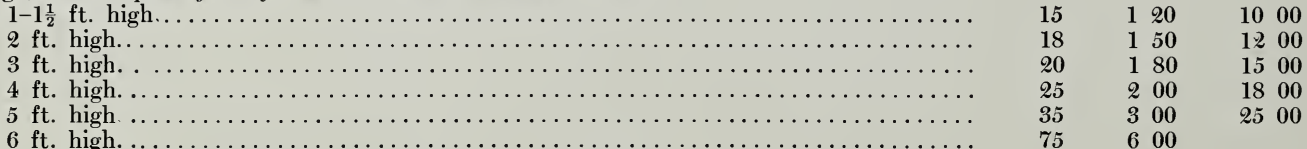

Tamarisk. Tamarix africana.

$2-3 \mathrm{ft}$. high. . . . . . . . . . . .

Viburnums.

Almost indispensable in the formation of a good landscape. Healthy and vigorous in foliage, white flowers not over showy at various seasons followed by blue, black, and bright red berries. The Japanese Bush Cranberry, Viburnum dilatatum, is probably one of the least known, still one of the most valuable. Scarlet fruit in profusion from September on.

Viburnum dentatum.

1-1 $\frac{1}{2} \mathrm{ft}$. high.

15

$2 \mathrm{ft}$. high.

2

$120 \quad 1000$

urnum molle; syn., V. Nepalense.

3 ft. high. .

$4 \mathrm{ft}$. high. .

30

200

1500

5-6 ft. high.

600

5000 


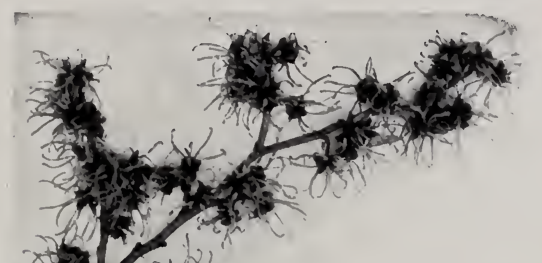

You will enjoy a whiff of spicy fragance from this the middle of December. The yellow blossoms come out after severe frost. The next September the seeds shoot twenty feet. Try a branch in the house. We have big sturdy bushes six years old.

\section{DECIDUOUS SHRUBS - Continued.}

Witch Hazel. Hamamelis Virginiana.

$1 \mathrm{ft}$. high. .

$3 \mathrm{ft}$. high.

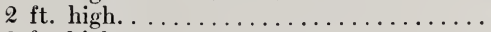

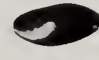

Viburnum lantana. 2-3 ft. high.

\begin{tabular}{|c|c|c|}
\hline Each & Per 10 & Per 100 \\
\hline & $\$ 120$ & $\$ 1000$ \\
\hline 20 & 180 & 1500 \\
\hline 30 & 250 & 2000 \\
\hline
\end{tabular}

$30 \quad 250$

Per 100

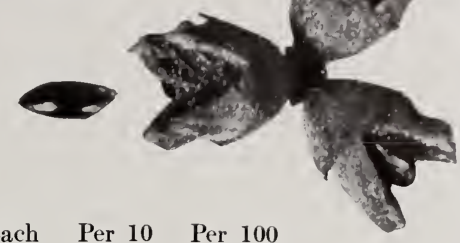

\section{Each Per 10}

$\$ 250$

Viburnum dilatatum.
$2 \mathrm{ft}$. high.
$3 \mathrm{ft}$. high.

$\begin{array}{lll}40 & 3 & 00 \\ 50 & 4 & 00\end{array}$
$4 \mathrm{ft}$. high.
100
400

Viburnum Opulus. High Bush Cranberry.

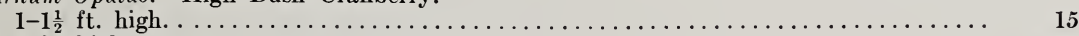

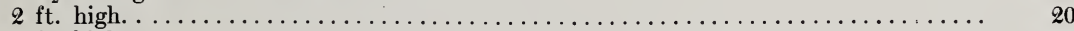

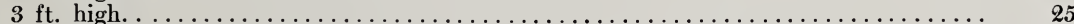

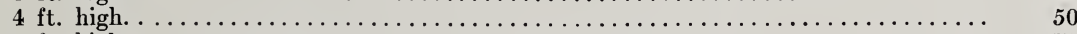

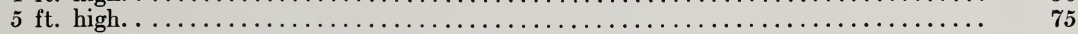

Viburnum Opulus, var., sterile. Common Snowball.
$1 \frac{1}{2} \mathrm{ft}$. high.

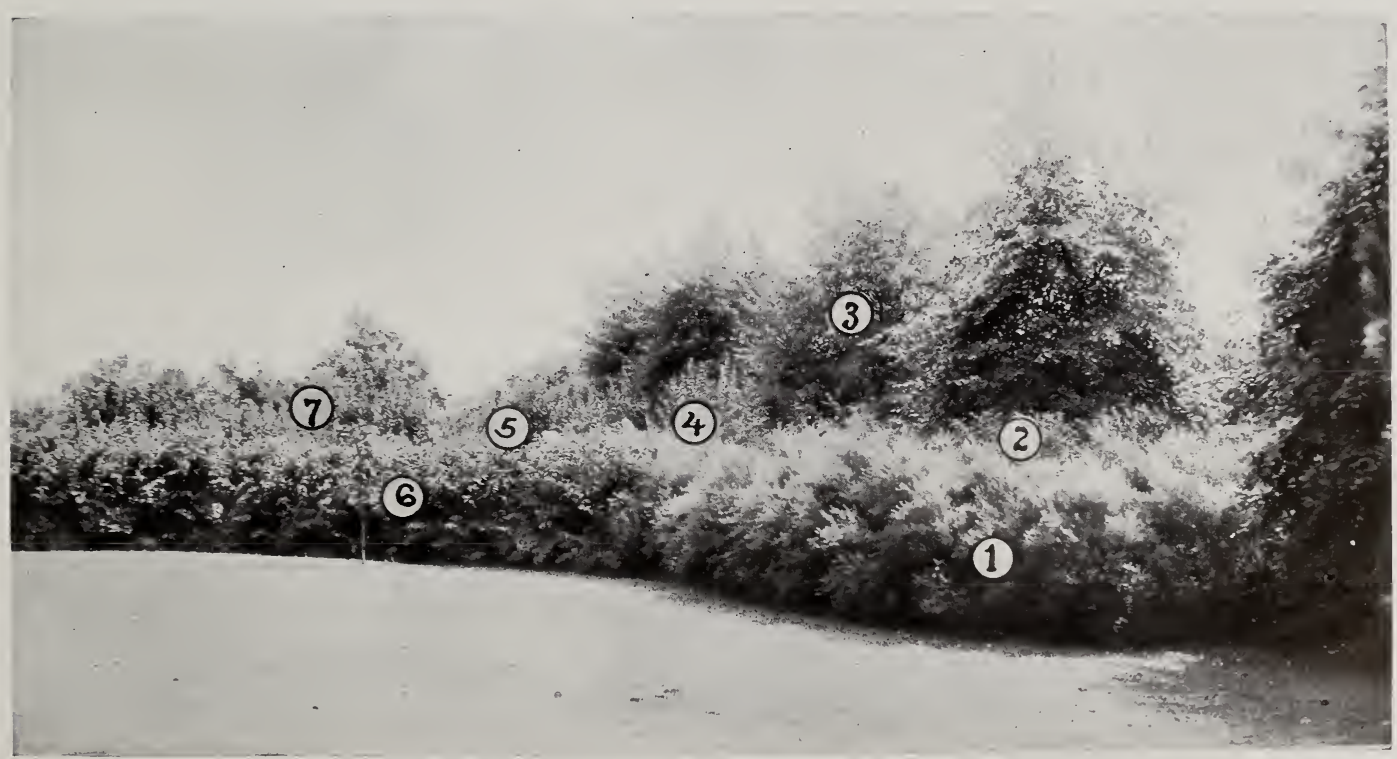

You would not suspect there was a service drive, and garden in back. This same group in May or June, would show a bank of bloom. However, healthy, vigorous toliage throughout the season is the main consideration. Possibly you have use for a similar planting. No. I is Spirea Thunbergii, graceful in foliage and attractive in flower. No. 2 is Spirea Van Houtti, the best of the Spireas. No. 3 is Small Leaf Linden giving stability and height. No. 4 is Lilac.; Upright Honeysuckle or Deutzia might be more ideal as the foliage does not mildew. No. 5 is Hydrangea; possibly a little overshowy. Viburnums might preferably be used. No. 6 is Rhodotypus. No. 7 Syringa. 


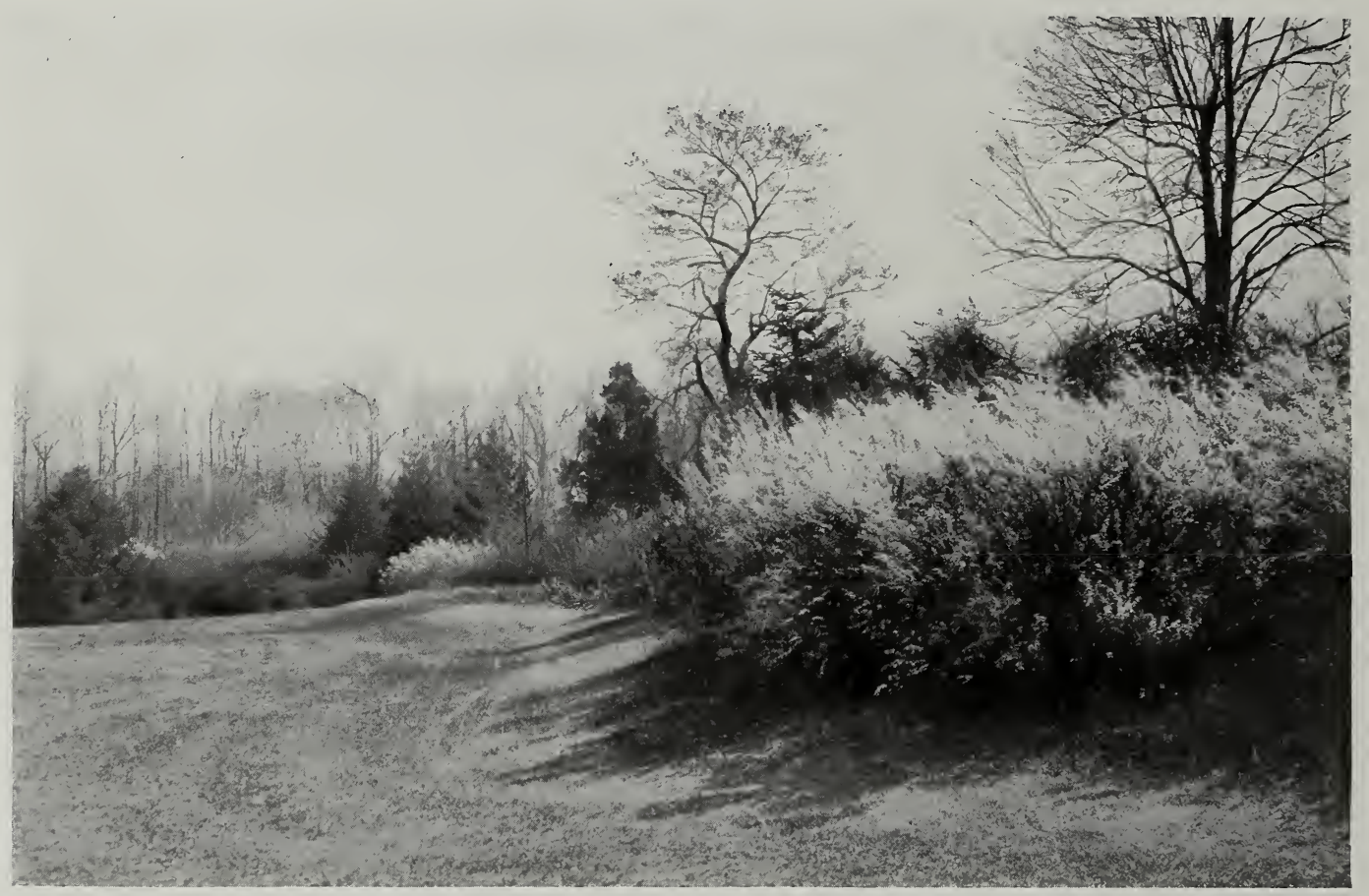

The white spot in the landscape is Spirea Thunbergii. This is one of the earliest white flowering shrubs. Its restful and pleasing foliage is well illustrated in the picture on page II. The virture of a landscape, however, is not proclaimed by this or any particular shrub, but by a careful design in masses, with bays and projections of varying height and a liberal area of lawn. Groups of Evergreens strengthen the landscape, especially in winter.

\section{DECIDUOUS SHRUBS - Continued}

Weigelia candida. (White).

$3 \mathrm{ft}$. high. .

$\begin{array}{rrr}\text { Each } & \text { Per } 10 \\ \$ 25 & \$ 2 & 00\end{array}$

$4 \mathrm{ft}$. high.

Per 100

Weigelia florida rosea.

$1 \mathrm{ft}$ high.

$1 \frac{1}{2}-2$ ft. high.

$3 \mathrm{ft}$. high.

15

20

120

180

$\$ 1000$

igelia floribunda.

$2 \mathrm{ft}$. high.

3-4 ft. high.

$20 \quad 180$

$30 \quad 250$

Willow, Japanese Pussy. Salix multinervis.

, Japanese Pussy. Salix multinervis.

$30 \quad 250$

2000

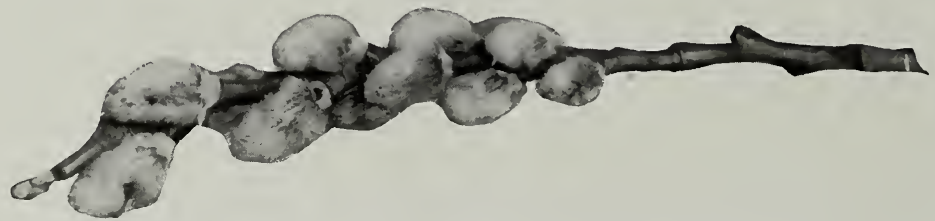

Pussy Willow. Always the first item in the garden diary. Too impatient to wait for spring, it bursts its silky catkins in February and March 


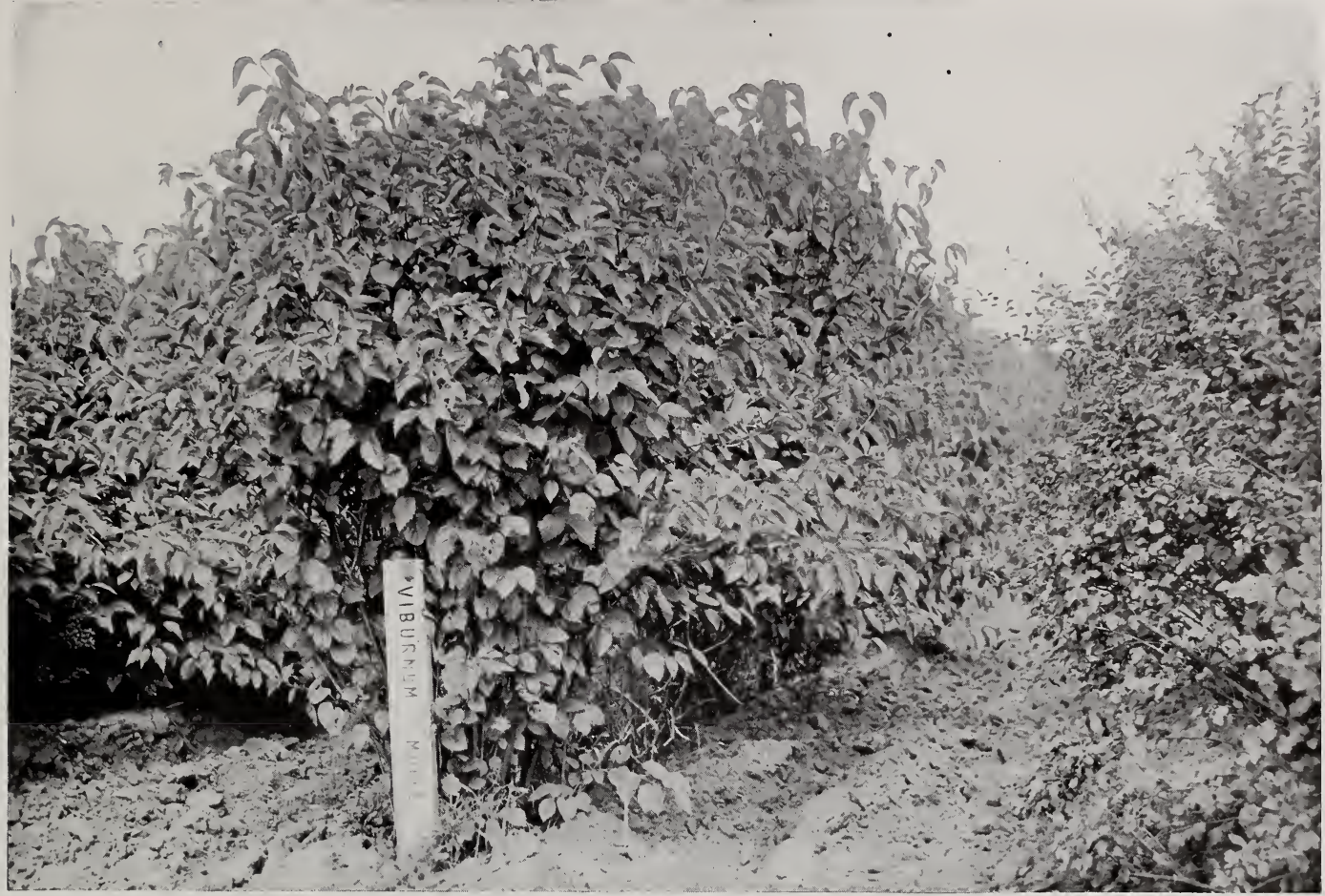

Block of big shrubs planted six by six feet. The usual distance is three feet by one foot. These large shrubs are especially valuable for screening about the service court or planting around the foundation of a new house. Nothing settles a house in the landscape more quickly than big round masses of foliage in the harsh angle with the ground. A group of trees twenty-five feet high, such as we have in large quantity, will do it also, but the
big shrubs will be needed to balance the composition.

\section{Big Broad Bushy Shrubs}

They are all specimens, seven years old, as thrifty plants as we have ever offered.

Don't confuse them with crowded, ill-shaped, left-over shrubs, the nurseryman usually discards. They are ideal for immediate screens, and if we figure correctly the cheapest screen for their height.

Forsythia Fortunei.

6-7 ft. high, 4-6 ft. spr.

Each Per 10

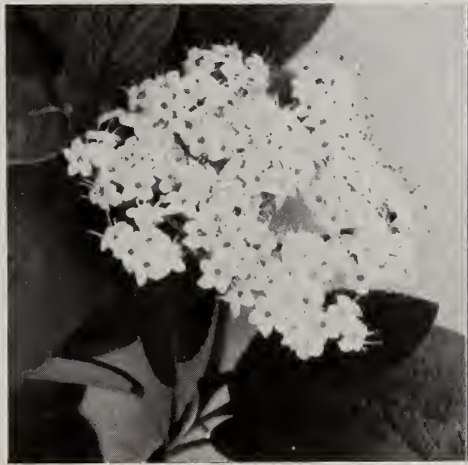

Viburnum Lantana. White flowers in May, followed by pink, red and black fruit, with the advancing season. Grows six feet.

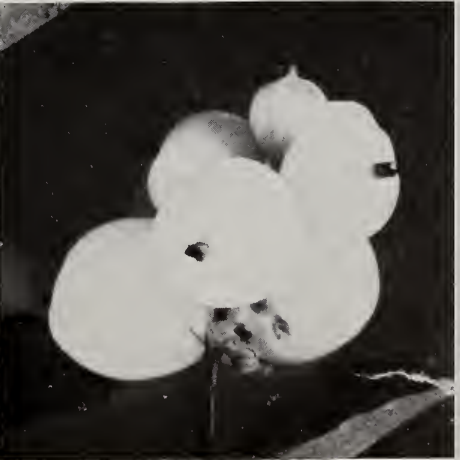

White SNowberRy. Waxy berries from September until frost.
$\$ 200$

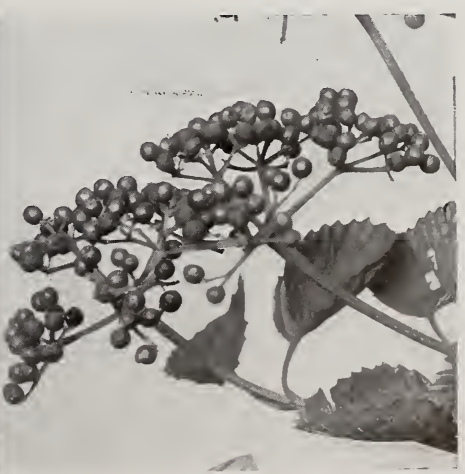

Viburnum Dentatum. Unexcelled for healthy tember. 


\section{BIG BROAD BUSHY SHRUBS - Continued.}

Honeysuckle, Upright.

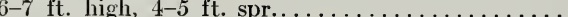

Spirea Van IIoutii.

$5 \mathrm{ft}$. high, $3-4 \mathrm{ft} . \mathrm{spr} \ldots \ldots \ldots \ldots \ldots \ldots \ldots \ldots \ldots \ldots$

Syringa (Mock Orange). Philadelphus coronarius.

6-7 ft. high, 3-4 ft. spr.................. 200

Viburnum dentatum.

$5-6 \mathrm{ft}$. high, $4 \mathrm{ft} . \mathrm{spr} . \ldots \ldots \ldots \ldots \ldots \ldots \ldots \ldots, \quad 300$

300

2500

Viburnum Lentago.

5-6 ft. high. 3-4 ft. spr. ................

Viburnum Molle; syn., Nepalense, see illustration p. 13. 5-7 ft. high, $4-6 \mathrm{ft}$. spr..................

300

2500

Viburnum Tomentosum.

$5-6 \mathrm{ft}$. high, $4-5 \mathrm{ft} . \mathrm{spr} \ldots \ldots \ldots \ldots \ldots \ldots \ldots$

300

Weigelia Rosea.

5-6 ft. high, $4-5 \mathrm{ft}$. spr...................

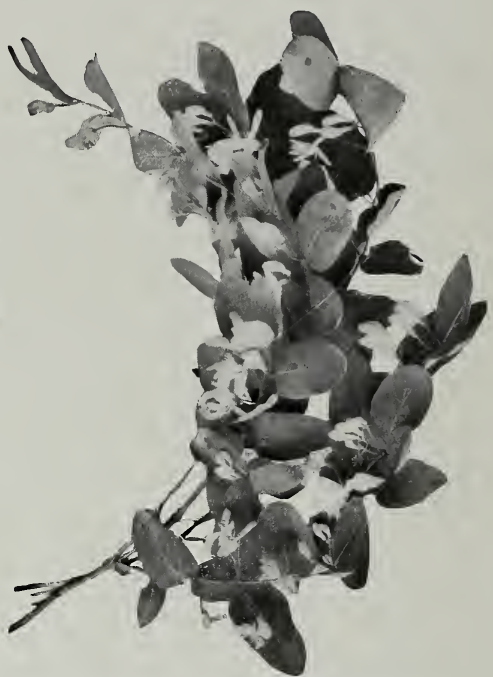

UPRIGHT HoNeysuckle. Always admired for its pretty pink flowers and transparent red berries. It grows big and sturdy and is capable of constitut ing the backbone of shrub planting. clusions.

If you examine the Hicks Nurseries, you may come to these con-

Trees that accurately fit the conditions where they are to be planted. Advice to discourage you from planting trees where they will not continue happy and beautiful.

Little trees, one to five years old, at low cost and in large quantities.

Trees of the usual sizes of highest possible quality with big system of fibrous feeding roots; broad, symmetrical tops, prices moderate in consideration of the high quality and system of growing them wide apart.

Larger trees fifteen to twenty-five years old that save you many years waiting. There are thousands to select from, trees twenty to forty feet high, twelve to twenty-five feet spread of branches and roots.

Our large tree-moving department for moving shade trees up to fifty feet high, forty feet spread of roots and tops, one and one-half feet in diameter.

Evergreens up to forty feet high.

November is the time to arrange for moving large evergreens this winter. Send for our pamphlets, showing carloads of Pines, fifteen feet high; Cedars, twenty-five feet high; and other evergreens, we can supply from our nursery or the collecting fields; and big evergreens we can move in your vicinity.

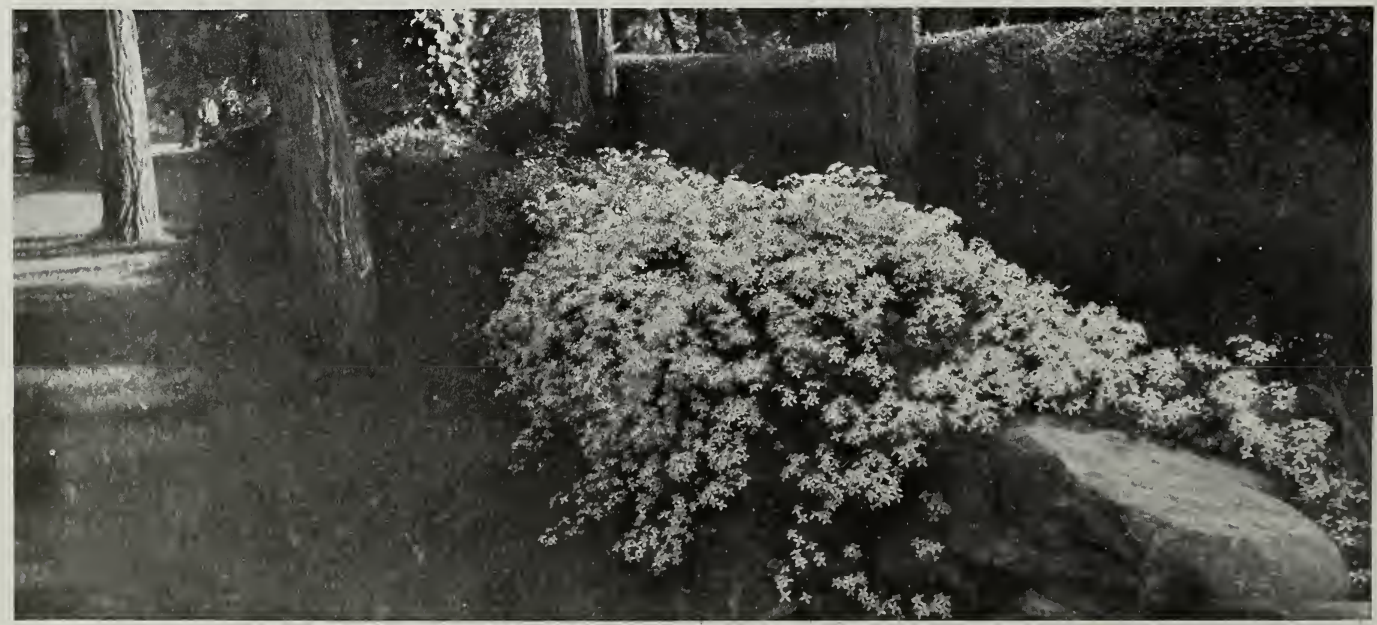

Clematis Paniculata. The one with small, scented flowers in August. It delights to ramble over any unsightly object, bank, fence, or trellis. When in bloom it has little competition among vines. 


\section{Vines}

The value of a vine lies not so much in its ability to accomplish certain results, but rather the short time required to do it. For subduing the bald aspect of buildings and walls, they are the sole means. Poles, Trellises, Poultry wires, tennis backstops, are magically transformed to objects of attraction. Steep banks can be kept from washing by a tangle of Ivy, Clematis, Roses and Wisteria, and what could be prettier? Frequently it is difficult to get plants to grow where shade is dense. This is quickly solved by the use of appropriate vines. Areas in shrubbery borders can be appropriately devoted to masses of vines. Nature gives many hints for effective uses. The hedge rows, old rail fences, dead trees, rocks, are some of the prettiest objects in her composition, made so by the beautiful draperies and festoons of the Ivies. These same vistas with their fall coloring, have undoubtedly already left their impression. Often the dusty roadside is rendered beautiful by the wild array of vines. It is possible to use Virginia Creeper and Honeysuckle with confidence.

Bitter Sweet, Japanese. Celastrus articulata.

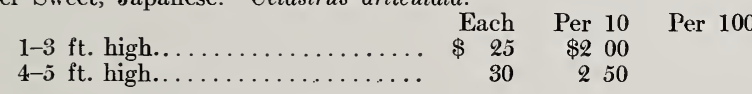

Dutchman's Pipe. Aristolochia Sipho.

$2-3$ ft. high. . . .

Clematis paniculata.

$6-12$ in. high.............. $15 \quad 120 \quad 1000$

Euonymus radicans. Narrow-leaved.

$6-12$ in. high............... $20 \quad 125 \quad 1000$

Euonymus radicans, vegetus. Broad-leaved 4-6 in. high. ................

$20 \quad 180 \quad 1500$

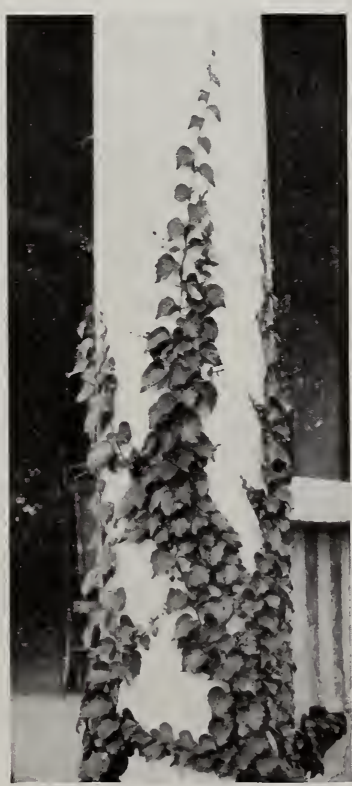

Boston Ivy. The most in demand for covering rocks, foundations,
walls, etc. Gorgeous in the fall.
Euonymus radicans. If some one would establish a popular name for this hardy evergreen vine, it would become as popular as Japanese Ivy. It is hardy where English Ivy gets the foliage browned or the branches killed back. Plant it in the woods, along foundation walls, fences, and in shady corners. Euonymus vegetus. One conspicuous lack of Long Island landscape is evergreens. This vine will make many a dull spot look cheerfull in winter,

Honeysuckle; Hall's Japanese. Lonicera Japonica, var., Halleana. 1-3 ft. high (\$60 per 1000).

Per 100

Ivy, Japanese or Boston. Ampelopsis tricuspidata, syn., eitchi. 6-12 in. high. . . . . . . . . . . . . . . .

Matrimony Vine. Lycium.

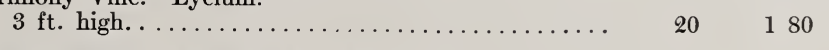

Virginia Creeper. Ampelopsis quinquefolia.

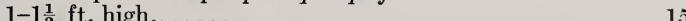

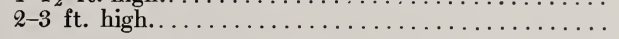

Wisteria, Chinese. Wisteria Chinensis; syn., Kraunhia

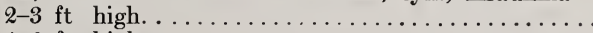

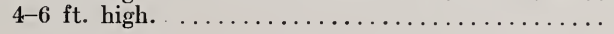

$20 \quad 180$

$25 \quad 200$

$50 \quad 400$ 


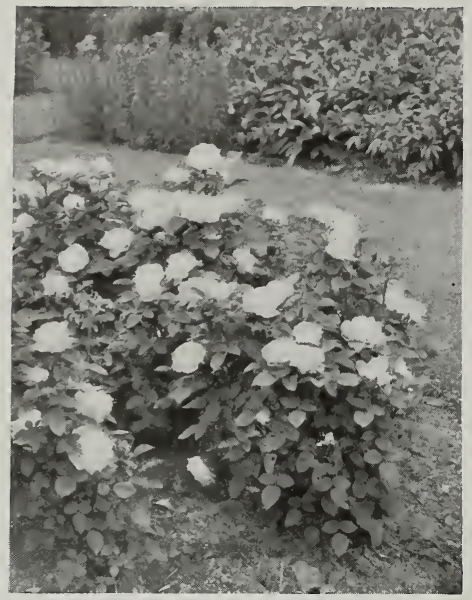

A Rose BeD is not an unreasonable ambition. Prepare the soil to a depth of eighteen inches by digging in well-rotted horse or cow manure; cultivate freely during the summer; bank the earth around the plants for the winter, and cover with leaves. Apply manure liberally.

\section{Roses}

Hybrid Perpetual Roses.............. $\begin{array}{rrrr}\text { Each } & \text { Per } 10 & \text { Per } 100 \\ \$ 2 & 30 & \$ 20 & 00\end{array}$

Do not use these with the anticipation of continuous blooming. They produce abundant bloom in June, but only occasional blossoms during the summer. Every spring they should be cut back from one half to two thirds, and are better if given slight protection during the winter. Manure heavily and keep the ground loose all summer.

Anna de Diesbach.......... Carmine, large fragrant, vigorous.

Baron de Bronstetten. . . . . . Maroon, fragrant, large and full.

Baroness Rothschild......... Delicate pink, large and full.

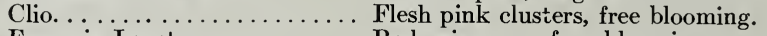

Francois Levet........... Red, vigorous, free blooming.

Frau Karl Druschki. ........ . Pure white, prolific vigorous.

Gen. Jacqueminot. .......... Crimson, large, abundant, fragrant.

Jules Margottin........... Carmine, luxuriant foliage.

Madam Gabriel Luizet...... Pink, beautiful, slightly fragrant.

Magna Charta.......... Pink, large fragrant.

Mrs. John Laing......... Pink, large, very hardy.

Paul Neyron............ Pink, very large, free blooming.

\section{Climbing and Trailing Roses .......... $\quad 30 \quad 250$}

2000

If you have no shrubbery for these to clamber over, no bank for them to cover, no tree-trunks for them to climb up, no fence for them to ramble on, no retaining wall for them to fall over, no arbors, arches, or pergolas for them to entwine, no waste portion of ground for them to carpet, then grow them for their own beauty of flower and vigorous healthy foliage.

The following are almost entirely free from leaf troubles or winter-killing

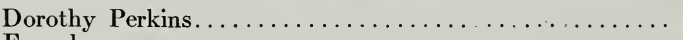
Farquhar. . . . . . . .

Hiawatha. ...............................

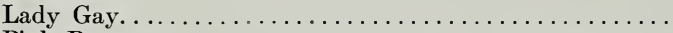

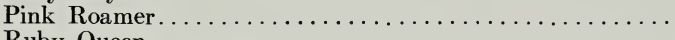

Ruby Queen.

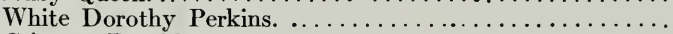

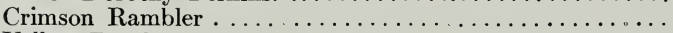

Yellow Rambler...............................

Prairie Rose.... .........................

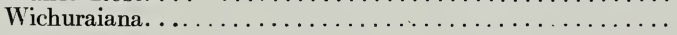

Large clusters, double pink, healthy.

Bright, double pink, vigorous, glossy foliage.

Single, bright crimson, vigorous, free flowering.

Similar to Dorothy Perkins, possibly slightly deeper.

Single, pink, with bright stamens.

Double, deep pink, borne singly.

Same as Dorothy Perkins, except color.

Exceedingly hardy and vigorous. Frequently mildews.

Cream when open, spicy, foliage glossy.

Single pink, in clusters. July.

Single white, golden stamens, glossy, bright foliage.

\section{ROSA RUGOSA}

Here is something you can plant at the edge of the ocean besides Privet. You will also find it satisfactory and appropriate among shrubbery, on road banks and in situations where high cultivation must be denied. These are worth planting for their dense, dark green, healthy foliage alone. The single and double, white and pink flowers, succeeded by red fruits an inch in diameter are additional features. Cut back every two or three years to keep compact.

Each Per 10 Per 100

Rosa Rugosa Rubra........ Single red. $\quad \begin{array}{rrrr}\$ & 25 & \$ 2 & 00\end{array} \quad \begin{array}{ll}\$ 18 & 00\end{array}$

Rosa Rugosa Alba......... Single white.

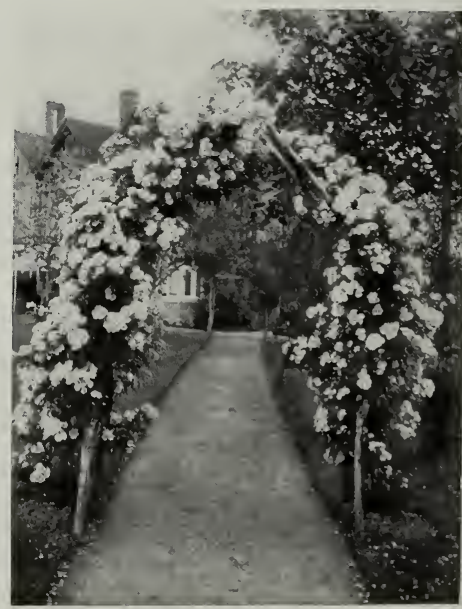

Climbing Rose. Meets almost as many demands as the Honeysuckle or Clematis. In fact, the thoughtful planter uses them all, and has a beautiful landscape, the whole season. once a month. For mildew; powdered sulphur. Rose bug; hand picking in the early morning.

\section{SPRAYING ROSES}

For green fly or aphıs and other sucking insects, whaleoil soap (1 tb. to 8 gals.) just before the leaves open and every twenty days to July first.

Mildew and black spot; Bordeaux mixture, diluted one half strength, (1) 


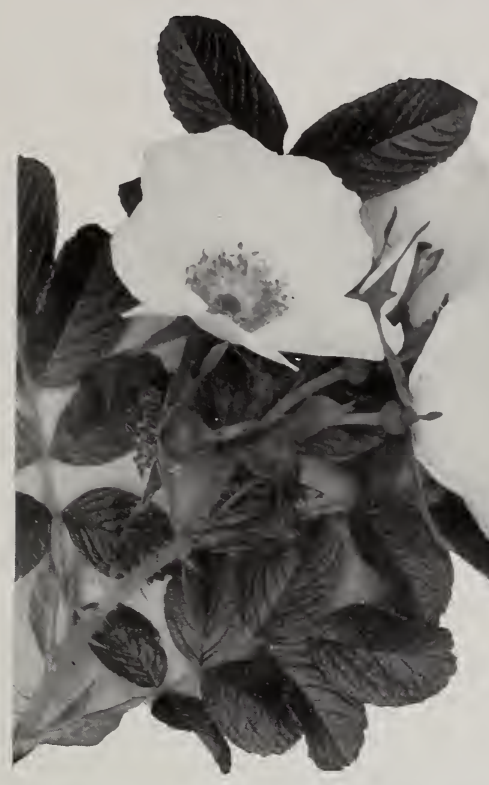

\section{Hardy Garden Flowers}

Do your grounds look sombre during September and October? A few moments in this department will show you how it is possible to make the premises vie with spring in its rich display of color, in fact, there need be no period without its wealth and variety of bloom. Possibly the ecstasy of decorating the home with flowers fresh from the garden has never been a reality. Or you may be alert for improved varieties or rare shades. We are situated to help you in either case. Plant now! In November the beds or border should be mulched with eight inches of leaves (those you usually burn), or very light strawy manure. This mulch can be kept in place by chicken wire, limbs, or a light laver of soil.

Our plants are all field-grown, and are nearly all large clumps, larger than usually sold. Note also the low prices at which they are offered. This permits their use in large quantities for naturalizing, cover planting, and large groups in shrubberies. Lower rates on large quantities of our selection.

The list we offer is carefully selected. We aim to grow only the best of each species, and have eliminated, as far as possible, undesirable colors; for we wish our patrons to feel that they can be sure of obtaining the effects desired.

Nothing can be more old-fashioned or lovelier than a garden in July filled with the tall spires of single Hollyhocks in the beautiful shades which we offer. Special attention has been given to securing the best colors. Our mixture is delightful, and the separate colors, so rarely found, are also offered; the crimson and the pink in quantity.

We offer a few single named varieties raised from English seed of the

RojA Rugosa. For seashore, banks, among shrubbery in groups. etc., large single and double flowers fol-
lowed by red hips one inch in diameter. Dark green, leathery leaves. newest varieties, such as Wearne Wyche, Rosy Morn, Whistler, Field of War, Cadbury, etc., at $30 \mathrm{c}$ each, $\$ 2.50$ per 10 . Set of 10 varieties, $\$ 2.7 \tilde{j}$.

\section{Those starred are especially adapted for cutting.}

*Achillea ptarmica fl. pl, "The Pearl"..

Each Per 10 Per 100

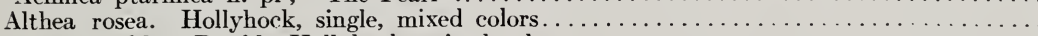

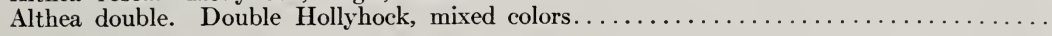

$\$ 10 \quad \$ \quad 90 \quad \$ 800$

$15 \quad 125 \quad 1000$

Alyssum, pumila, Saxatile Compactum. For use back of low border plants such as Iris and Moss pinks this should be used lavishly.

Alyssum saxatile compactum. Golden Tuft........

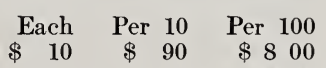

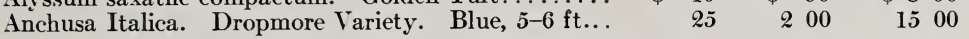

It is surprising how few know it. It never fails to excite admiration. It is the bluest flower we have. The summer sky appears faded in comparison. It occupies the period prior to Delphinium and Veronica, and blooms more abundantly. We have anticipated a large demand and propagated accordingly.

Anemone Japonica, var., alba. Japanese Windflower

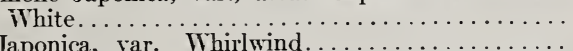

A. Japonica, var. Whirlwind........................

$\begin{array}{lllll}15 & 1 & 25 & 12 & 00 \\ 15 & 1 & 25 & 12 & 00 \\ 15 & 1 & 25 & 12 & 00 \\ & & & & \\ 15 & 1 & 25 & 10 & 00 \\ 15 & 1 & 25 & 10 & 00 \\ 15 & 1 & 25 & 10 & 00 \\ 15 & 1 & 25 & 10 & 00 \\ 15 & 1 & 25 & 8 & 00\end{array}$

Aquilegia, var. Chrysantha. Golden Columbine.

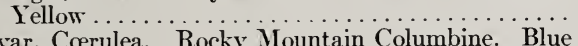

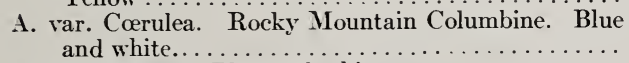

A. var. Helenæ. Blue and white..................
A. Nivea grandiflora. Long spurred white........

Aranis Alpina. Alpine Rock Cress. White..........

Aquilegia. The grace of the long spurred Columbines is indispensable as a combination with the statelier iris.

A. Fine mixed. . . . . . . . . . . . Armeria plantaginea. Thrift. Sea Pink. Rose pink.

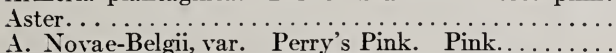

A. Novae-Belgii, var. Perry's Pink. Pink..........

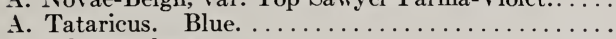

10

10

15

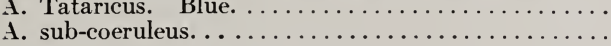

Bellis Perennis. English Daisy...

$\begin{array}{rrrrr}90 & & 7 & 00 \\ 80 & & 5 & 00 \\ 1 & \mathbf{2 5} & & & \\ 1 & \mathbf{2 5} & & 8 & 00 \\ 1 & \mathbf{2 5} & & 8 & 00 \\ 1 & \mathbf{2 5} & & 8 & 00 \\ 1 & \mathbf{2 5} & & 8 & 00 \\ & & & & \\ 80 & & 5 & 00\end{array}$

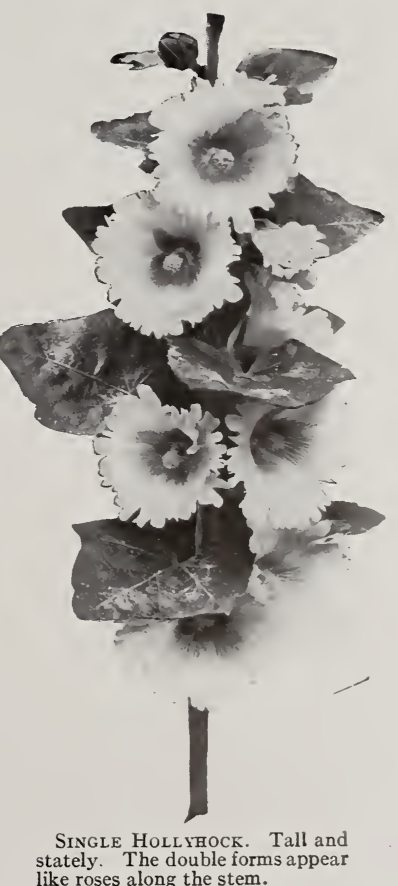

stately. The double form
like roses along the stem. 


\section{HARDY GARDEN FLOWERS-Continued.}

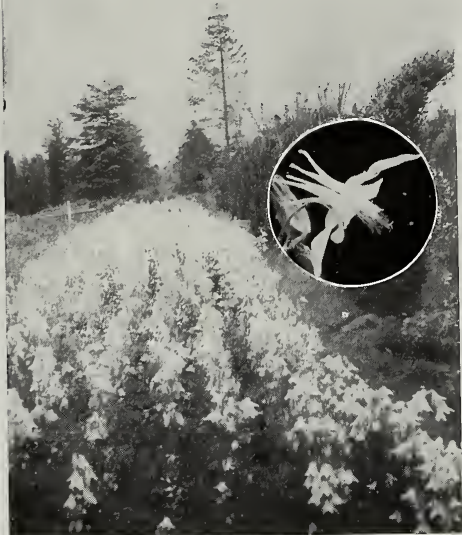

AQUilegia. With long stems and such fascinating flowers, the temptation to cut for boquets is irresistible.

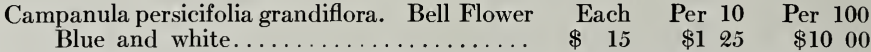

This is one of the best and most vigorous of the Campanulas. We offer a very large stock of fine heavy plants which will make a great show the first season.

C. medium. Canterbury Bells. Blue, pink and white.

C. Carpatica. Carpathian Harebell. Blue

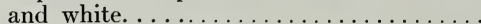

Clematis recta. White. .................

Chrysanthemum, Pompon:

Myer's Perfection. Pure white anemone

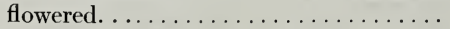
Anna Mary. Cream white, shaded pink.

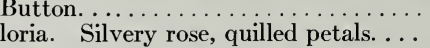
St. Iloria. Silvery rose, quilled petals. ...

Rhoda. Pink, shaded white. Button. . . . Julia Lagravere. Crimson maroon. . . . . . . . Sylvia. Scarlet-bronze. Tall. ............. Alice Cary. Pure yellow. Button....... Urith. Bronze, tipped yellow............

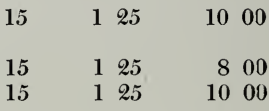

$\begin{array}{lllll}10 & 90 & & 6 & 00 \\ 10 & 90 & & 6 & 00 \\ 10 & 90 & & 6 & 00 \\ 10 & 90 & & 6 & 00 \\ 10 & 90 & & 6 & 00 \\ 10 & 90 & & 6 & 00 \\ 10 & 90 & 6 & 00 \\ 10 & 90 & 6 & 00 \\ 10 & 90 & & 6 & 00\end{array}$

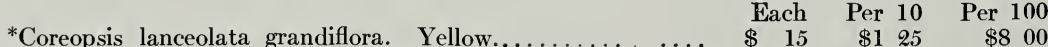
Convallaria majalis. Lily-of-the-Valley. ................. $\quad 10 \quad 80 \quad 5.00$

The low price at which this is offered permits its use in large quantities, and the clumps we send out can be divided to make small plants. There are many places where it is appropriate as a cover plant.

*Delphinium. Larkspur. Formosum, dark blue .......... D. grandiflorum, var. Chinense. Gentian blue................. D. Gold Medal Hybrids. Shades of blue, mostly light......... $\quad \begin{array}{lll}15 & 125 & 10\end{array}$ *D. Kelway's Choice Show. Mixed .............. We have a large stock of this grown from Kelway's seed. Very lovely sliades.

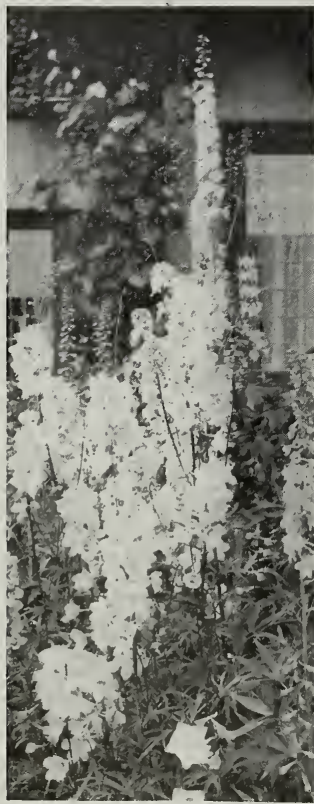

Delphinium. Makes the border or garden a deluge of blue of most exquisite hues.

*Dianthus. Hardy Pinks, White

Reserves, Her Majesty and

Mrs. Simkins. Pure white,

clove scented.......... $10 \quad 90 \quad 800$

Dianthus Latifolius atrococcineus. (Everblooming $\mathrm{Hy}-$ brid Sweet William.) Crimson. Excellent for bedding, blooming all the season.

D. Chinensis. China Pinks. Crimson and salmon.........

*D. Barbatus. Sweet William. Pink, white and crimson.

Dicentra spectabilis. Bleeding Heart Pink.

Digitalis. Foxglove, var. gloxiniæflora. Rose colored.

D. Purewhite $(\$ 60.00$ per M).

10

10

15

15

125

125

800 and is equally appropriate for naturalizing among trees and shrubs.

Funkia. Plantain Lily. Day Lily in variety.........

${ }^{*}$ Gaillardia grandiflora. Blan-

ket flower. Yellow, ver-

milion, and crimson...... $\quad 15 \quad 125 \quad 800$

There is no plant in the garden to which one may go with more confidence of always finding good cut-flowers than to this. The stems are long and the rich bronze, red and yellow flowers will harmonize with most interiors.

Hemerocallis. Yellow Day Lily, var. Dumortierii........ *Heliopsis laevis, var. Pitcheriana. Yellow.............

*Helianthus rigidus, var. Miss Mellish. Yellow..........

*Gypsophylla paniculata. Baby's Breath..............

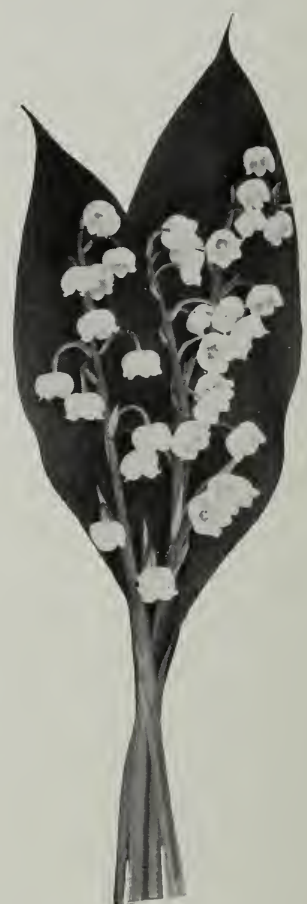

LiLy of THE VALLEy. Ours are good clumps. Try them in that shady corner where so few things will thrive.

$\begin{array}{crrr}\text { Each } & \text { Per } 10 & \text { Per } 100 \\ 15 & 125 & 800 \\ 10 & & 90 & 800 \\ 15 & 1 & 25 & 1000 \\ 51 & 1 & 25 & 1000\end{array}$




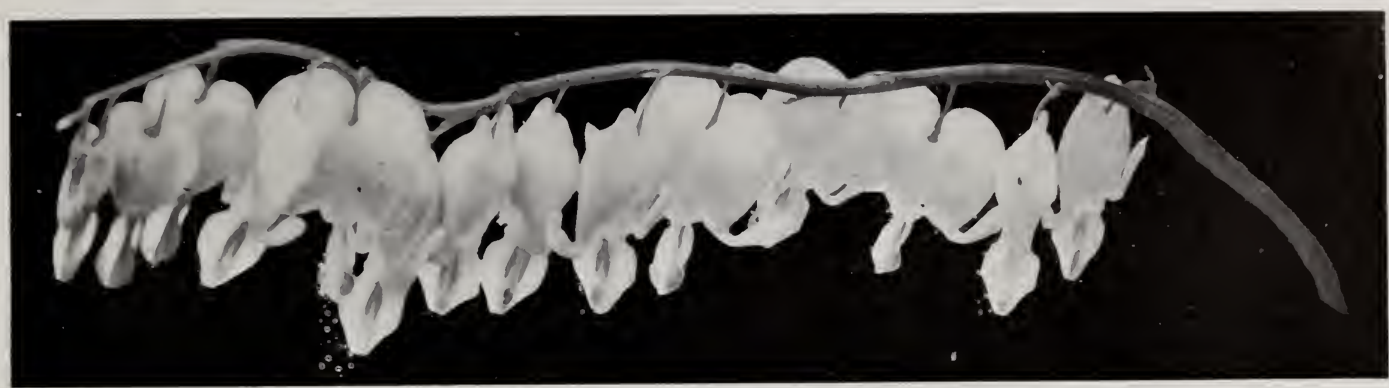

BLEEDING HEART. Seemingly created for children to dissect, forming miniature bunnies, bellows, slippers, etc.

\section{HARDY GARDEN FLOWERS - Continued.}

\begin{tabular}{|c|c|c|c|}
\hline & Each & Per & Per 100 \\
\hline H. flava. Lemon Lily. & & $\$ 1$ & $\$ 800$ \\
\hline H. florham. Yellow. ........... & 20 & & 1500 \\
\hline H. Thunbergii. Thunberg's Day Lily & 15 & & \\
\hline Heuchera sanguinea. Coral Bells.... & 15 & & 10 \\
\hline Hibiscus Moscheutos. Mallow. $\ldots \ldots \ldots \ldots \ldots$ & 15 & & \\
\hline $\begin{array}{l}\text { ypericum Moserianum. Gold Flower. St. } \\
\text { Johnswort. } \ldots \ldots \ldots \ldots \ldots \ldots \ldots \ldots\end{array}$ & & & \\
\hline $\begin{array}{l}\text { Eris. Hardy Candytuft, var. sempervirens. } \\
\text { Evergreen Candytuft. White. . . . . . . }\end{array}$ & 15 & & \\
\hline
\end{tabular}

Iris Germanica. German Iris. Fleur-de-lis:

Nothing ever discourages this species and its site always looks well in the garden, even after flowering. The variety Walnerii is a light blue variety which we offer at low rates and recommend for planting both in ordinary soils among shrubbery and in damp situations.

Purple King. Rich, deep, velvety, purple.... Spectabilis. Light and deep violet-purple.....

Walnerii. Light blue ( $\$ 60$ per M) .........

$\begin{array}{llll}25 & & 2 & 00 \\ 15 & & 1 & 25 \\ 15 & & 1 & 25 \\ 25 & & 2 & 00\end{array}$

200

125

200

800 1800

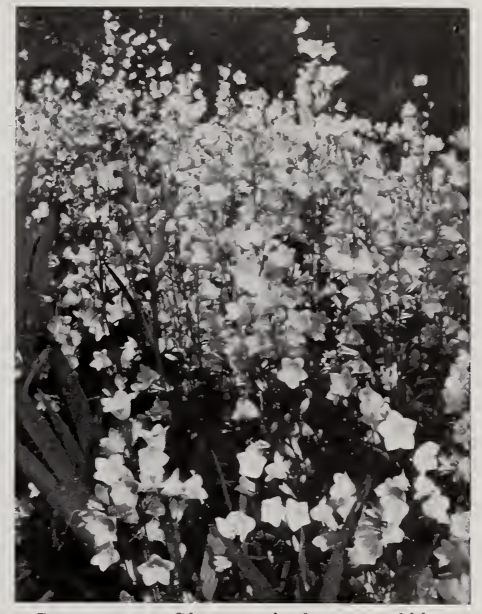

CAMPanula. Give an unbroken area of bloom. and lend dignity to any garden.

\begin{tabular}{|c|c|c|}
\hline Each & Per 10 & Per 100 \\
\hline 15 & $\$ 125$ & \\
\hline & 125 & \\
\hline 25 & 200 & \\
\hline 15 & 125 & \\
\hline 25 & 200 & \\
\hline 15 & 125 & \\
\hline 25 & 200 & \\
\hline 15 & 125 & $\$ 1000$ \\
\hline 15 & 125 & \\
\hline 15 & 125 & 10 \\
\hline
\end{tabular}

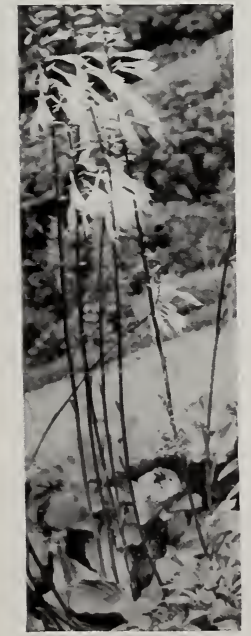

Plantain Litu. Adapted for beds, borders, and shrubbery. Healsome flowers.
Queen of May. Soft lilac, almost pink.....

Cengialti. S. Lavender blue. F. Violet blue.

Ceni King S. Golden yellow, F. Telvet

Honorabilis. S. Golden. F. Rich brown. ..................

Dr. Bernice. S. Coppery bronze. F. Velvety crimson. . . . . . . . .

Jaquesiana. S. Bright coppery crimson. F. Maroon.

Bridesmaid. S. White, shaded lavender. F. Lavender. .

Madam Chereau. White, frilled blue.

Mrs. H. Darwin. S. Pure white F. White and violet...

Iris Florentina. Orris Root. White suffused lilac................

I. pumila hybrida:

This is one of the welcome flowers of early spring. It is one of the first Iris to bloom and is the most showy flower of its season. Fine for edging.

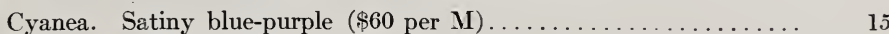

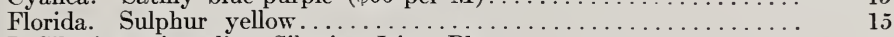

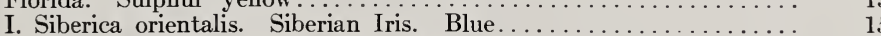

I. Kæmpferi. Japanese Iris: pure white ........................... 25

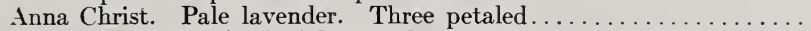

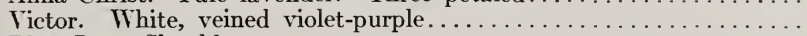

Blue Jay. Sky blue...

Blue Danube. Indigo Blue.

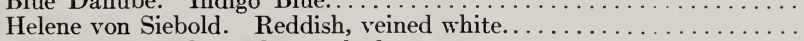

Paragon. Royal purple, marked orange.

Kniphofia tritoma. Red Hot Poker Plant. Orange, scarlet and yellow

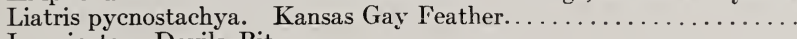

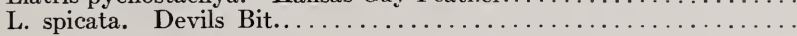

$\begin{array}{rrrrr}1 & 00 & & 8 & 00 \\ 1 & 00 & & 8 & 00 \\ 1 & 00 & & 8 & 00 \\ 2 & 00 & 15 & 00 \\ 2 & 00 & 15 & 00 \\ 2 & 00 & & 15 & 00 \\ 2 & 00 & & 15 \\ 2 & 00 & & 15 & 00 \\ 2 & 00 & & 15 & 00 \\ 2 & 00 & & 15 & 00 \\ 2 & 00 & & \\ 2 & 00 & & 15 & 00 \\ 1 & 25 & & 10 & 00 \\ 1 & 25 & & 8 & 00 \\ 1 & 25 & & 8 & 00\end{array}$




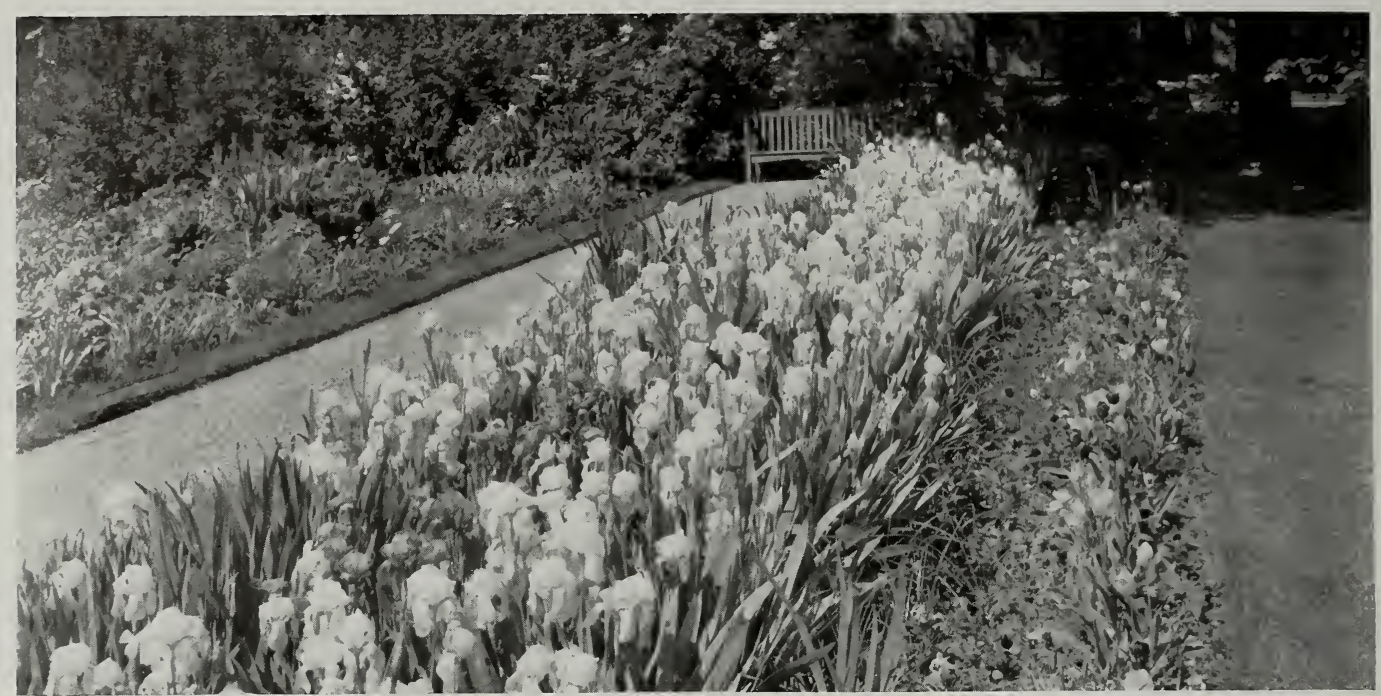

IRIS. Almost as rich as the orchid. By using the Pumila Hybrids, German. and Japanese varieties, you have iris for eight weeks.

\section{HARDY GARDEN FLOWERS - Continued}

L. latifolia alba, var. "The Pearl," White. . . .
Lavendula vera. Lavender. . . . . Lespedeza Sieboldi; syn. Desmodium punduliL. Sieboldi alba. Pure white. . . . . . . . . . . . . .

Latris pycnostachya. Kansas Gay Feather.

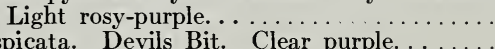

L. spicata. Devils Bit. Clea

L. speciosum album. White. .

L. speciosum rubrum. Deep pink. . . C . . . . . .
Lobelia cardinalis. Cardinal flower.

Lupinus polphyllus. Lupine. Blue...

Lupine should be planted in quantity, especially the pure white.

L. polyphyllus, var. albus. White...........
Lychnis chalcedonica. Lamp Flower. London Pride. Orange-scarlet.

L. Viscaria fl. pl. German Catchfly. Double

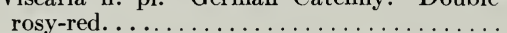

This can be used for carpet-bedding because of its even and intense color.

When out of flower it is a particularly attractive clump of grass-like foliage.

Monarda didyma. Bee Balm. Oswego Tea.

"Cambridge Scarlet".......................

Myosotis. Forget-me-not. Blue...........

\begin{tabular}{|c|c|c|}
\hline Each & Per 10 & Per 100 \\
\hline$\$ \quad 15$ & $\$ 125$ & $\$ 1000$ \\
\hline 15 & 125 & 1000 \\
\hline 20 & 150 & 1200 \\
\hline 25 & 200 & \\
\hline 15 & 125 & 800 \\
\hline 15 & 125 & 800 \\
\hline 25 & 175 & \\
\hline 15 & 125 & 1000 \\
\hline 15 & 125 & 1000 \\
\hline 15 & 125 & 1000 \\
\hline
\end{tabular}

$15 \quad 125$

15100

800

800

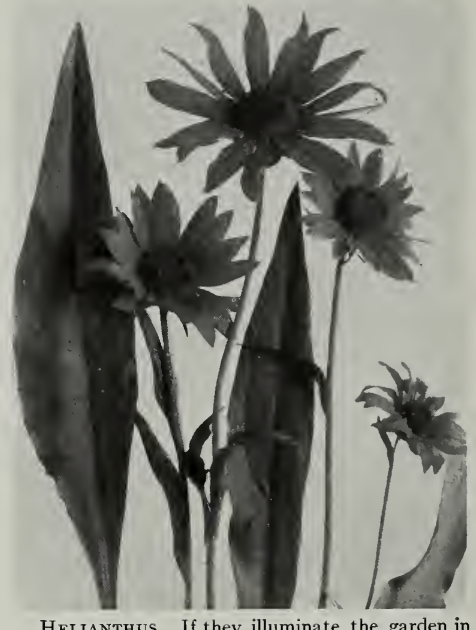

Helianthus. If they illuminate the garden in sunlight they cannot help but illuminate the interior on dull days. Long stems and long season,
July to October.

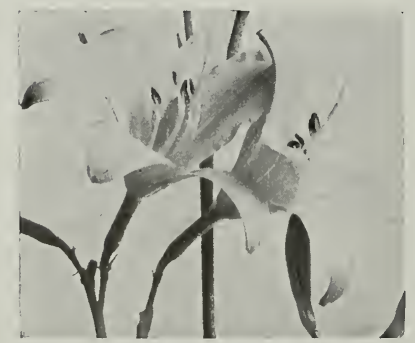

Hemerocallis Flava or yellow day-lily a beautiful, sweet scented flower that is
found in every good garden.
Narcissus incomparabilis. Star Daffodil. Single yellow ( $\$ 600$ per M. $\$ 50$ per $10 \mathrm{M})$. .

$\begin{array}{rcr}\text { Each } & \text { Per } 10 \\ \$ \quad 15 & \$ 75\end{array}$

Per 100

N. poeticus. Poet's Narcissus. Fragrant, pure white $(\$ 7$ per $\mathrm{M})$.

15

75

These clumps can be planted from our Nursery even when in flower. In the early spring when they are in bloom is the time to send us an order for a few thousand to be planted in September. They may be dotted through the grass. The simplest way to plant them is with a sharp stick.

*Oenothera fruticosa, var. Youngii. Yellow. ...... $\quad 15 \quad 125$ 


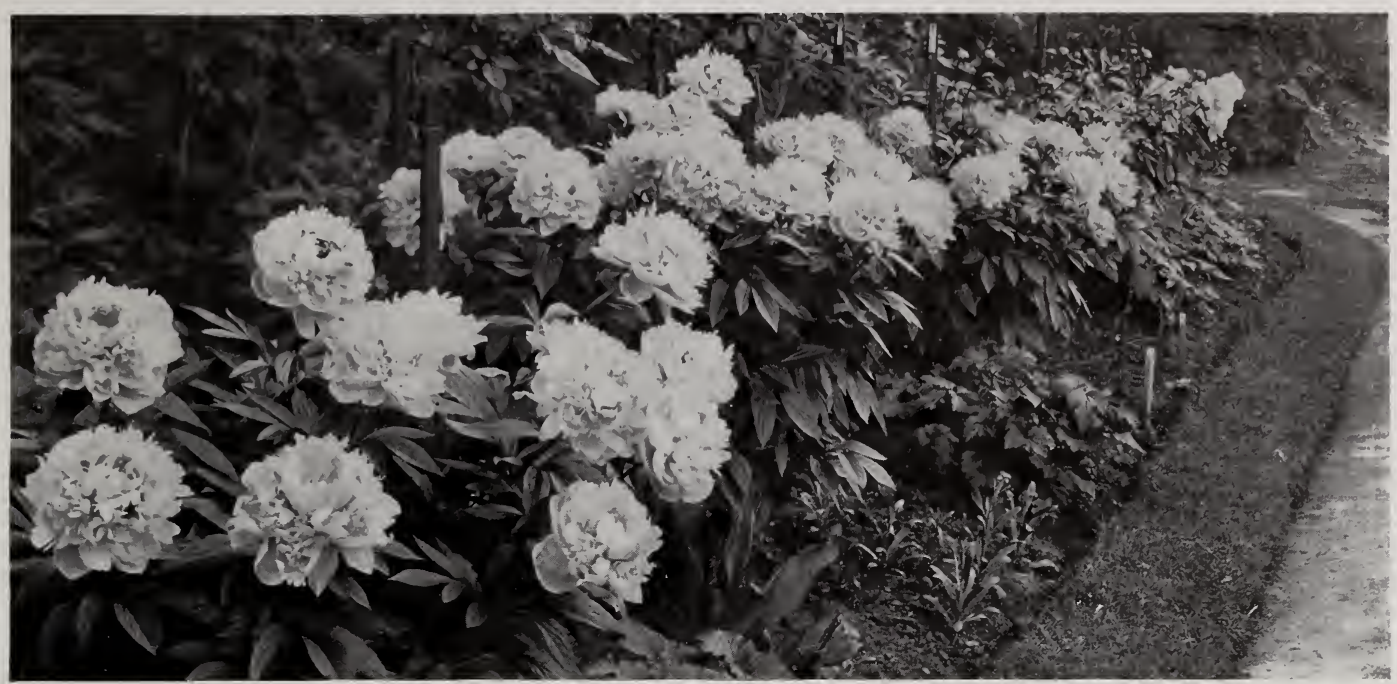

Pxony. They reward you annually without toil or effort. The immense blooms are very decorative.

\section{Paeonia Sinensis. Peony.}

Within the last half century wonderful improvements have been made in the Peony, and to-day for size, beautiful coloring and fragrance no hardy garden plant surpasses it. The roots may be planted any time from the middle of August until the ground freezes, and very early in the spring before growth has advanced too far. Spring-planted Peonies will not bloom the first summer and typically perfect blossoms are not produced till the second or third year. June.

Peonia, Festiva maxima. White; early. An enormous snow-white...

Each Per 10 Per 100

Madam Crousse. White; midseason. One of the finest pure whites. . .

$\$ 50 \quad \begin{array}{rrrr}50 & \$ 40 & 00\end{array}$

Couronve D'Or. Crown of Gold. White; very late; large, imbricated petals intersper...

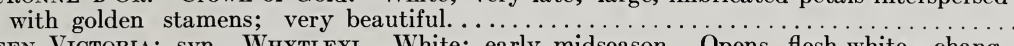

Queen Victoria; syn., Whytleyı. White; early midseason. Opens flesh-white, chang-

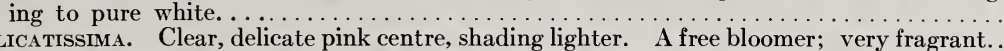

Delicatissima. Clear, delicate pink centre, shading lighter. A free bloomer; very fragrant.

HuMEi CARNEA. Large, cinnamon-scented flower of clear cherry-pink................

Felix Crousse. Late midseason; one of the finest brilliant reds. Glowing with ruby-

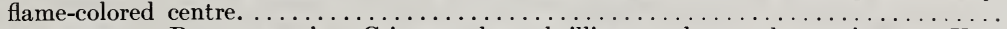

RUBRA sUPERBa, Richardson's. Crimson; late; brilliant, velvety, deep crimson. Very

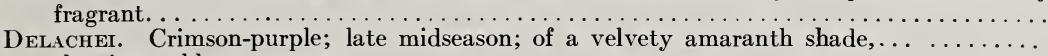

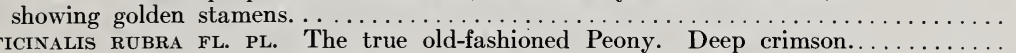

OfFICINALIS RUBRA FL. PL. The true old-fashioned Peony. Deep crimson.............
P. OFFICINALIS FL. PL. Which decorated our grandmothers gardens. It blooms about two weeks before other Peonies, and differs in that the foliage dies down in midsummer and should, therefore, be so planted that other flowers will cover the same space later. Deep crimson.

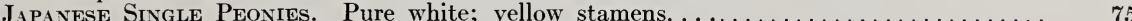

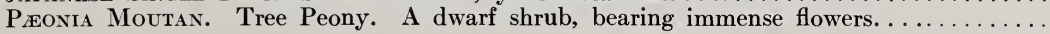

Papaver orientale. Oriental Poppy. For gorgeous display of intense vermilion or scarlet nothing rivals the great Poppies, frequently 8 inches across and borne on stems 3 feet high.

Papaver Nudicaule. Iceland Poppy. A charming flower which blooms all summer and especially in early spring and autumn. Beautiful shades of white, primrose, lemon, fawn, to orange. An excellent cut flower.

P. NUdicaule. Iceland Poppy. White, orange, and scarlet flowers.............

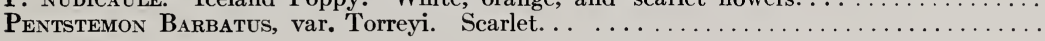




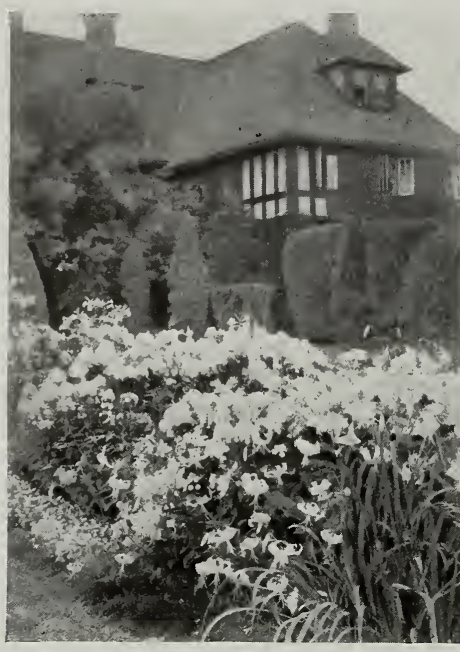

Used in variety, Phlox make the garden glow for a period ot two months. With Iris, Helianthus and Chrysanthemums the season is practically harmonious.

\section{Phlox}

We are proud of our varieties. The new Phloxes are so beautiful, and so varied in exquisitely delicate shadings, that there seems no excuse for the grower who continues to offer a long list plentifully sprinkled with rose-magenta, rose-mauve, rosy-lilac, and many less explicit descriptions, much to the mystification of the amateur who is trying to select a few harmonious shades. There are many indifferent, freaky or washy shades even in the best lists we have studied, which should not be offered. We offer none of the abhorred magenta. Our study and testing has been tireless and comprehensive. Each of the varieties offered below is distinct and the best of its color that we have seen. For color harmony consult us.

\section{WHITE}

\begin{tabular}{|c|c|c|c|c|}
\hline & & Each & Per & Per 100 \\
\hline INDEPENDENCE. & Tall. Early White. & & $\$ 1$ & $\$ 1000$ \\
\hline $\begin{array}{l}\text { QueEn. Tall. } \\
\text { SONNENKIND. }\end{array}$ & White........... & 15 & & \\
\hline & $\begin{array}{l}\text { Medium. } \\
\ldots \ldots \ldots \ldots\end{array}$ & 15 & & 1000 \\
\hline $\begin{array}{l}\text { red } \mathrm{e} \\
\text { red }\end{array}$ & & 15 & & 10 \\
\hline
\end{tabular}

\section{SALMON-PINK}

Lumineaux. Tall. A splendid, late-flowering, salmon-pink shading lighter toward the centre, with darker eye. A charming color. Flowers large. .....................

Elizabeth Campbell. New. A soft salmon shading to white in the centre with a touch of red at the eye. An unusual shade. .

Wolfgang von Goethe. Medium. Deep salmon-rose with large white centre......... L'Evenement. Dwarf. An even, bright salmon of satiny texture, with a showy blue-purple eye

The above four varieties are all distinctly different and together are charming. They harmonize perfectly, and may be safely planted with the white, scarlet, orange, and red varieties of our list.

\section{SCARLET AND ORANGE-RED}

George A. Strohlein. Brilliant orange-scarlet with blood-red eye. . . . . . . . . . . Matador. Medium. Large flowers of bright orange-red with cherry centre. . . . . . . . Coquelicot. Dwarf. Orange-scarlet with crimson eye. $\ldots \ldots \ldots \ldots \ldots \ldots \ldots \ldots \ldots \ldots \ldots$

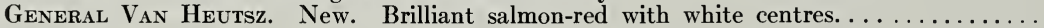

\section{RED TO BRONZE-RED}

R. P. Struthers. Tall. This is an excellent bright red, the flowers borne in open panicles much branched. A very vigorous, long-flowering variety....................

Fernand Cortez. Tall. Very large flowers of deep crimson, overlaid with coppery bronze;

a fine, strong grower.

LAVENDER-PINK AND ROSE-VIOLET WITH WHITE CENTRE

L'Esperance. Dwarf. Light lavender-pink, with large white eye................................
Edmond Rostand. Large trusses of reddish violet flowers with a large, white, star-shaped centre. ...

Phlox. Mixed.

P. suffruticosa. Early flowering. Miss Lingard, white, with pale pink eye $\ldots \ldots \ldots \ldots \ldots \ldots$

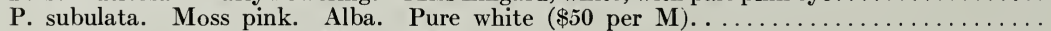
Lilacina. Light lilac $(\$ 50$ per $\mathbf{M})$. .

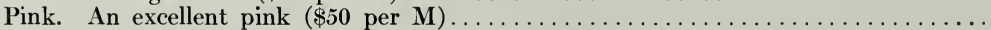

Physostegia Virginica. False Dragon Head. Pink and white. $\ldots \ldots \ldots \ldots \ldots \ldots \ldots \ldots$

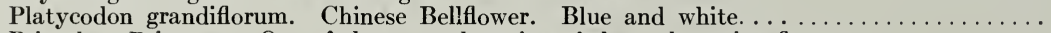
Primula. Primrose. One of the most charming of the early spring flowers.

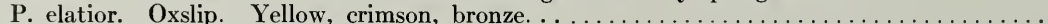

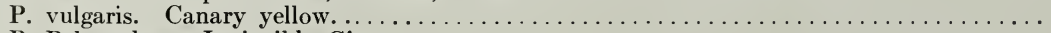

P. Polyanthus. Invincible Giant. .

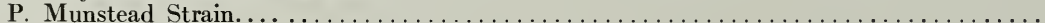

P. Pure white. ..............

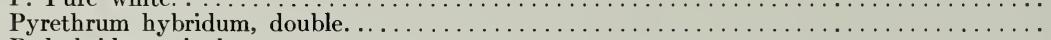

P. hybridum, single. 
HARDY GARDEN FLOWERS - Continued.

Rudbeckia laciniata. Golden Glow............
R. purpurea. Giant Purple Cone-flower. . . .
Salvia azurea, var. grandiflora. Meadow Sage. Blue.

Sedum acre. Stonecrop. Wall Pcpper. Yellow.

S. spectabilis. Stonecrop. Japanese Live-forever. Rosy-red

Spiræa Japonica. Astilbe Japonica. White... .

S. Kamtschatica or Gigantea. Cream white. ... .

S. palmata, var. elegans. Silvery-pink. .

Statice latifolia. Great Sea Lavender. Blue-

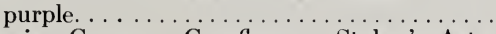

Stokesia Cyanea. Cornflower. Stokes' Aster $(\$ 60 \mathrm{M})$

$\begin{array}{rrrrr}\text { Each } & \text { Per } 10 & \text { Per } 100 \\ \$ 15 & \$ 100 & \$ 600 \\ 15 & 1 & 25 & 10 & 00 \\ 15 & 1 & 25 & 10 & 00 \\ 10 & & 50 & 3 & 00 \\ 15 & 1 & 25 & 10 & 00 \\ 15 & 1 & 25 & & \\ 25 & 2 & 00 & & \\ 15 & 1 & 25 & & \\ 15 & 1 & 25 & & \\ 15 & 1 & 25 & 8 & 00\end{array}$

This new plant is rapidly becoming popular, and those who do not have it should not delay. There are never enough blue flowers for cutting, and this is very welcome.

S. alba. Pure white. . .

Thermopsis Caroliniana. Yellow.

Thymus serphyllum, var. citriodorus. Lemon

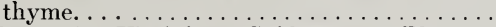

Tradescantia Virginica. Spiderwort. Blue or white.

Valeriana officinalis. Garden Heliotrope......

Veronica longifolia subsessilis. Blue Jay Flower.

Vinca Minor. Trailing Blue Myrtle or Periwinkle......

$15 \quad 125$

$15 \quad 125$

$15 \quad 125$

$15 \quad 125$

$15 \quad 125$
800

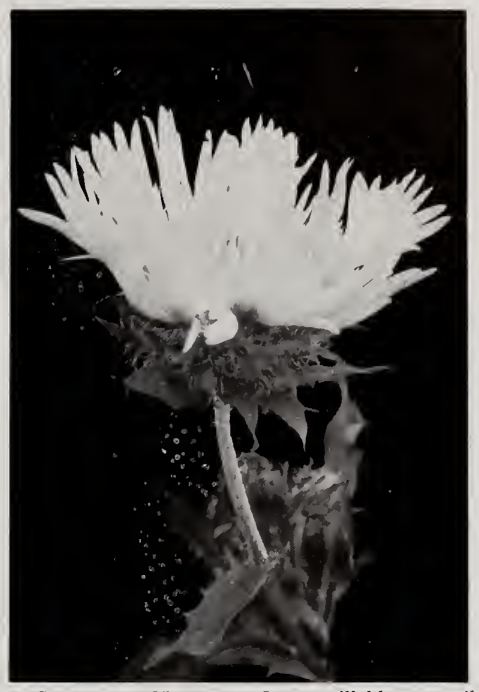

Stokesia. Not every flower will bloom until 1000

frost. This one does and starts in June.

$$
\begin{array}{rrrrr}
\multicolumn{2}{c}{\text { Each }} & \text { Per } 10 & \text { Per } 100 \\
\$ & 15 & \$ 1 & 25 & \$ 1000
\end{array}
$$

Both the blue and the white should be used extensively as cover planting in shady places.

V. minor, var. alba. White (Above is $\$ 60 \mathrm{M}) \ldots \ldots \ldots \ldots \ldots \ldots \ldots \ldots \ldots \ldots \ldots$

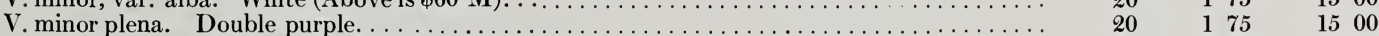

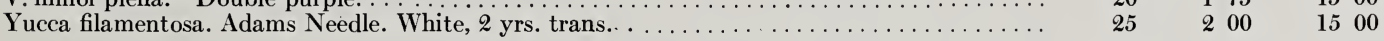

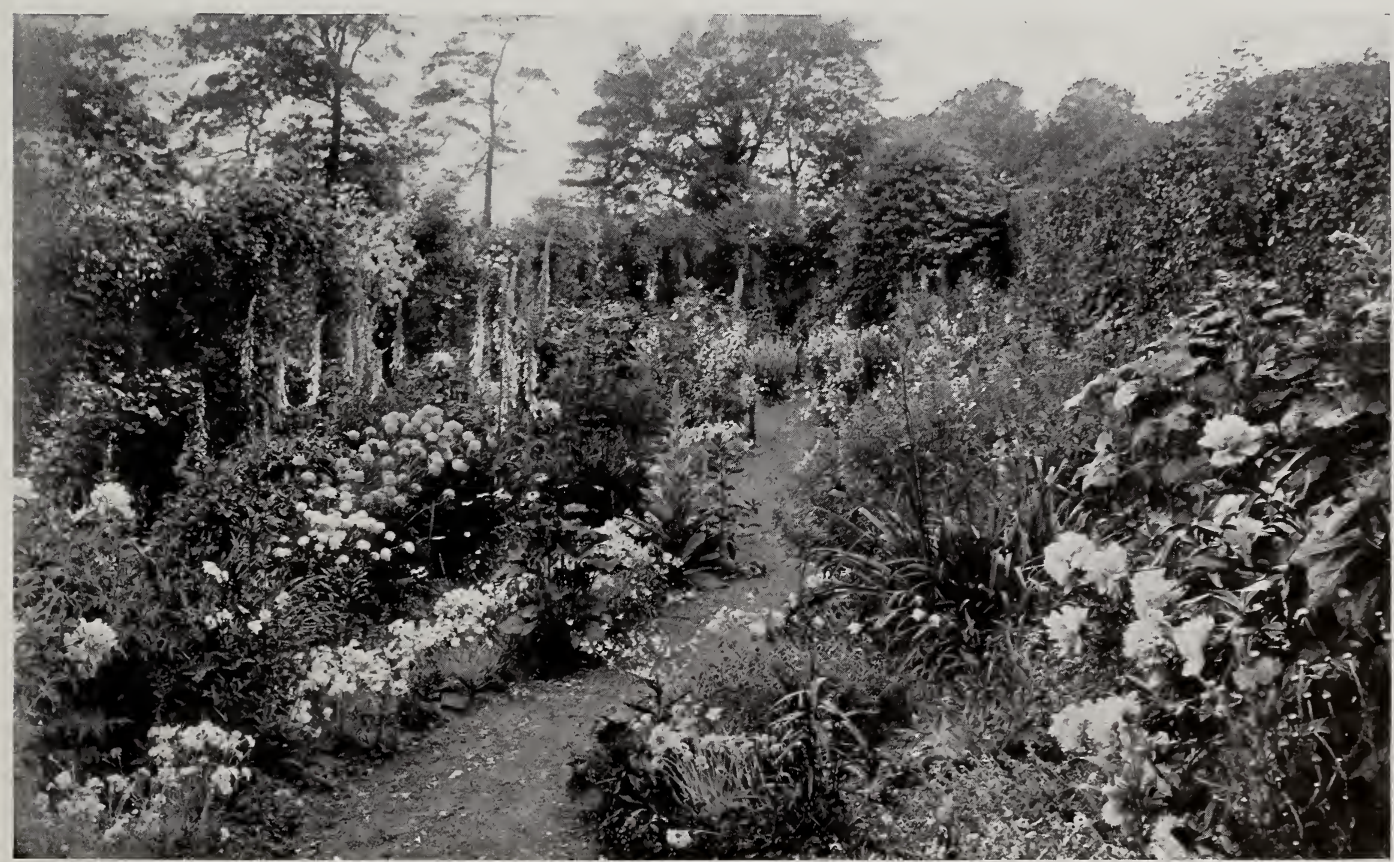

A garden where flowers are more important than the design. Have you not a piece of land you wish to make into a flower garden this fall? 


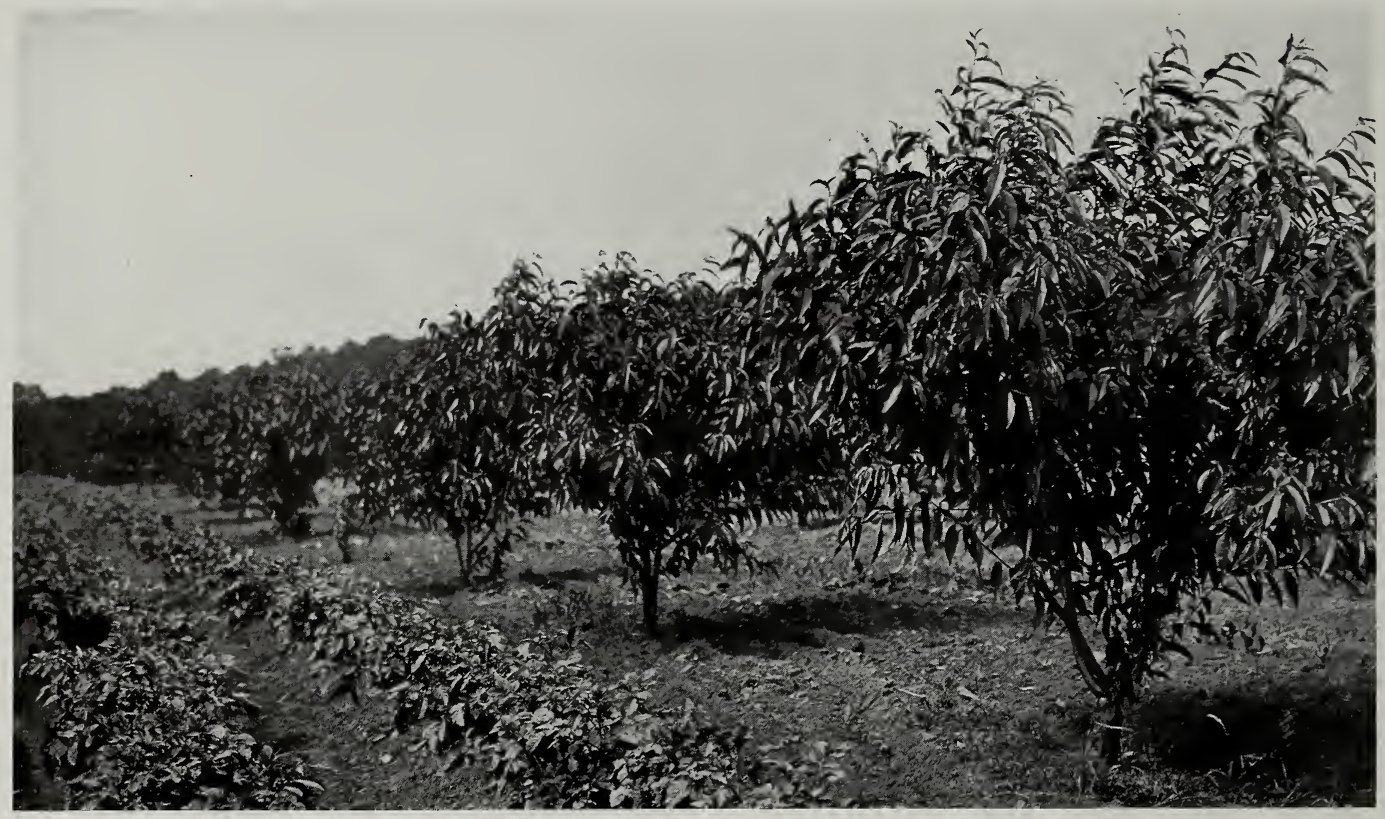

Peach Orchard. Probably one of the greatest hindrances to successful fruit raising is lack of cultivation. Plant vegetables between the rows and the trees are more apt to receive attention.

\section{FRUITS}

\section{How to Start and Maintain a Home Orchard}

You can have fruit in about eighteen months with Peaches and small fruits, and four to six years with Pears and Apples. You can gain but little by getting larger trees. Few, if any, are obtainable from nurserymen. You have got to establish the trees on your place before they will bear fruit, and it will take as long with a tree $8 \mathrm{ft}$ high and $1 \frac{1}{2}$ inch in diameter as with a tree 4 or 5 feet high and $\frac{3}{4}$ inch in diameter. Commercial growers find they get results just as quickly with even smaller trees. The important question is, not when you can get the first fruit, but when you can get the first peck of fruit from a tree.

Dwarf Apples and Dwarf Pears are grafted on roots which retard the growth and induce earlier bearing. However the advantage is slight except on very limited areas under high culture, and Long Island is not yet so crowded as to make the practice necessary.

Varieties for Long Island have been carefully tested in this establishment for the past sixty years. Like the size of the tree planted, the variety is less important than the cultivation. We have selected varieties which we consider good for home use on Long Island to cover the season.

The cultivation is $\mathbf{9 0}$ per cent. of the work in having fruit, pruning and spraying the balance. Many fruit trees fail to reach satisfactory development because they are set in the grass and let alone, or there is a little circle kept free of grass; this is only a fraction of the root-area. Extensive experiments in England and elsewhere show that grass appears to have a deleterious influence on fruit trees greater than the amount of food required. Whatever the reason, the fact remains that satisfactory orchards are plowed, harrowed or cultivated two or three times a month during the summer. The latter half of the summer may be devoted to the growing of crimson clover or hairy vetch to be plowed under the next year for manure. The value of cultivating is not primarily to kill weeds, but to conserve moisture and aërate the soil, helping the bacteria to make the plant-food available. The dust-mulch, to hold moisture, is especially essential on Long Island because of the porous subsoil.

The way to start a fruit orchard for home use is to plant the trees in rows 15 to 30 feet apart, and cultivate them with a horse so as to stir the surface soil 3 inches deep once every ten days from April to August or September. If you plant them in grass, you may plan to keep a circle around each tree cultivated, but it will not be done thoroughly by hand. The circle will not be wide enough, the ground will be scraped $\frac{1}{2}$ inch deep once in three weeks, just enough to keep away the weeds. The soil will become baked and hard, allowing the ground to dry rapidly.

Planting. - In planting, cut off bruised and broken roots, dig a hole wide enough to spread out the roots, and pack 


\section{FRUITS - Continued}

the earth firmly. Cut back the top severely, nearly or quite to a bare pole. Let new branches start out to form the new framework of the tree close to the ground and avoid having them opposite because they are more liable to split when heavily laden. Many fruit trees die because the full top is left on and the roots cannot support it. Few have the courage to prune because they think they are throwing away a year's growth.

Pruning.- Pruning fruit trees is a practical subject for large commercial growers. For the home orchard it is of less importance. Keep the trees headed low, so they may be thoroughly sprayed. Keep the tops open so that the sunlight reaches all parts of the foliage and gives the fruit a good color. Head back Peach trees to keep them so that the limbs will not be long and break down. Thin out the fruit in early summer to improve the size and flavor.

With Raspberries and Blackberries, cut out the old wood after the fruit has ripened, cut out all the young suckers as they appear during the summer except a few for next year's bearing, and cut these back during the summer to keep them from getting too high.

With Currants and Gooseberries, trim out a few of the oldest branches.

With Grapes, cut back every winter, leaving 2 to 4 buds about every foot along the arms, and when the arms get old and rough, replace with a young shoot. Spray Grapes several times during the summer with Bordeaux mixture to keep off mildew and rot. Put paper bags over the young clusters to keep off fungus, and keep away the birds."

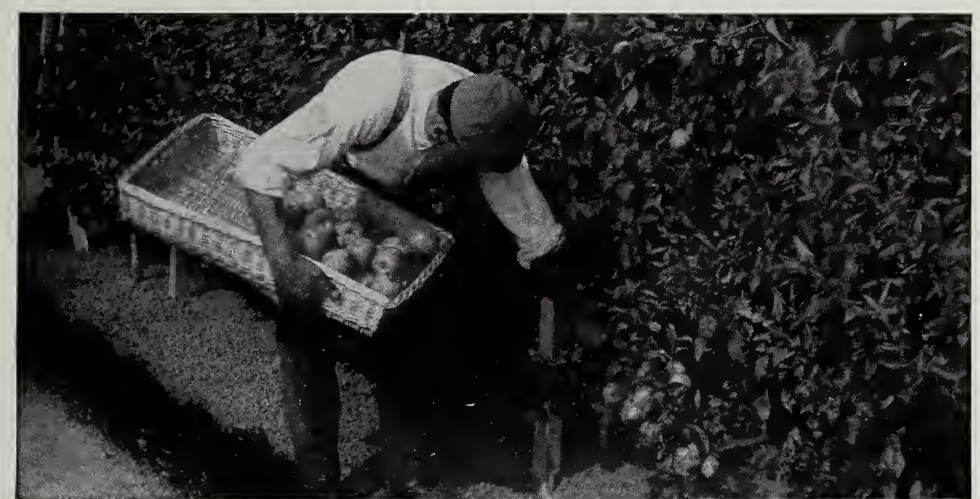

The new way of growing fruit is to plant dwarfs trained on trellies. No tall ladders to climb, easy to prune, spray, and pick the fruit.

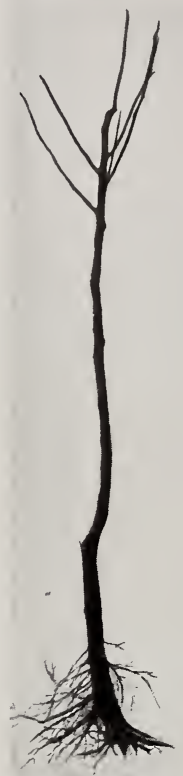

It takes courage to properly prune a newly set tree. The tree will lier if severely but earCut if severely cut back. like apple trees back trees to a and peach trees to a cane. The dead trees are lack of pruning and lack pruning and lack of by cultivating the ground 3 inches deep once in two weeks.

\section{APPLES}

Do not veto planting apples because you must wait two or three years. They will be sure to repay you for waiting.

Varieties starred can be supplied in dwarf form. Plant 10-15 feet apart.

Early Harvest . . . . . . . . L July and early August.

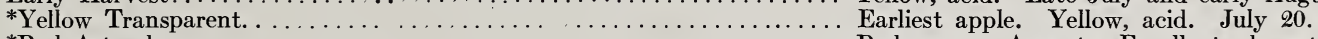

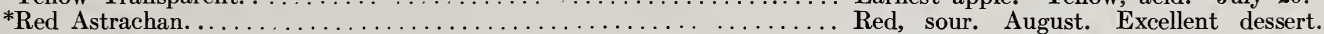

Sweet Bough. ................. Yellow, sweet. July and August.

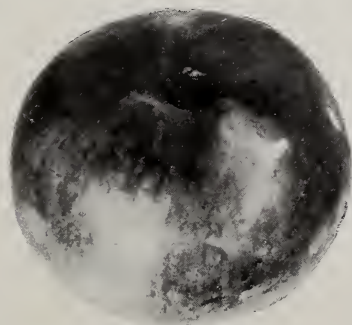

APple. Bright, clean fruit is the reward for the proper care. Feed your trees, cultivate often and spray, an
get your dividends in a better-harvest
Duchess of Oldenburg........... Yellow streaked, juicy, acid. August 15.

${ }_{*}$ Gravenstein..................... Yellow streaked. August and September.

Wealthy...................... Dark red, sub-acid. October-November. Bears early.

Fall Pippin. ................. Yellow, acid. October-November.

${ }^{*}$ McIntosh....................... Red, acid. September.

Fameuse. . . . . . . . . . . . . . . . . . Crimson, acid.

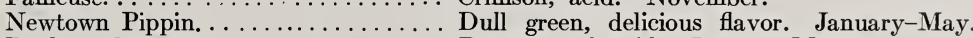

Roxbury Russet. ............... Russet, sub-acid. January-May.

*Baldwin. ................. Red, juicy and rich. November-April.

Spitzenburg.................

R. I. Greening..................... Green, rich, sub-acid. November-February.

Smokehouse................. Red and yellow, juicy aromatie. OctoberJanuary.

Transcendent (Crab)............. Yellow, red cheek. September.

Apples, 5-7 ft. high ............. Each, $\$ .75$ Per 10, $\$ 6.00$ Per 100, $\$ 50.00$

Apples, Dwarf. .................. $\quad .75$ Pach, $\$ .75$ Per 10, $\$ 6.00$ Per 100, $\$ 50.00$ 


\section{PEARS}

Those starred succeed especially as dwarfs and require little or no pruning. Their use is commended where areas are limited or early fruiting is an important consideration. They can be planted as close as ten feet.

Oxband's Summer.......... Yellow, sweet. August.

*Clapps Favorite. ........... Yellow, red cheek. Valuable. August.

${ }^{*}$ Bartlett. . . . . . . . . . . . Y Y Yllow, red cheek. August-September.

Sheldon. .............. Russet, coarse, fine flavor. September-October.

Seckel. ............. Brown, sweet and juicy. September-October. *Duchess d' Angouleme...... Yellow, large, buttery. October-November. *Anjou. ................ Green and russet, rich and buttery. OctoberNovember.

Winter Nellis. .. .......... Russet, rich, sprightly. November-December.

Price, 5-6 ft. high......... Each, $\$ 0.50$ Per $10, \$ 4.00 \quad$ Per $100, \$ 35.00$

\section{PEACHES}

Peaches planted in the fall in certain locations may freeze back to the trunk. Really, this is not serious. They should be cut back that far, anyway. but few have the courage to do it. Ripening about in order named.

Carman ............... Large, white, spicy. July.

Belle of Georgia. . . . . . . L Large, white, firm, delicious. August.

Champion ............. Large, white, juicy. August.

Mountain Rose......... Medium, white, prolific. August.

Crawford's Early........... Large, yellow. September.

Old Mixon. . ............. White. Excellent for canning. September.

Stephens Rareripe......... Large, red skin, flesh white. October.

Elberta. .............. Large, yellow, juicy and fine flavor.

Crawfords Late........... Large, yellow, red at the stone.

Stump the World .......... White, juicy and high flavored.

Chairs Choice............ Large yellow, firm, good quality.

Globe............... Large, yellow, sweet and delicious.

Price, 4-6 ft. high, 1 year.... Each, $\$ 0.25$ Per 10, $\$ 2.00 \quad$ Per 100, $\$ 18.00$

\section{PLUMS}

Those starred are Japanese Plums, peculiarly early and productive, but not always equal to the European Plums in quality. They are inclined to overbear, remedied by proper pruning or thinning of fruit.

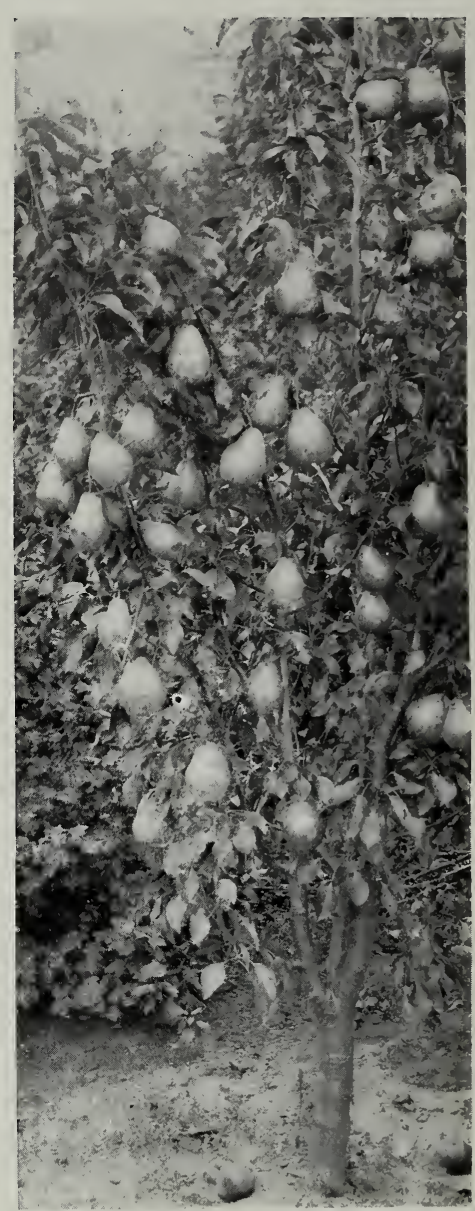

*Abundance.

Yellow, covered with red, productive. August.

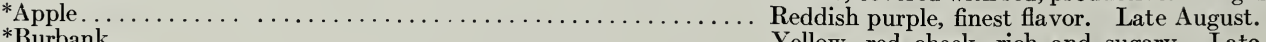

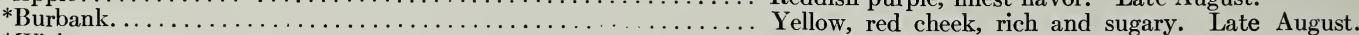

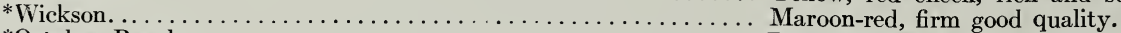

*October Purple. $\ldots \ldots \ldots \ldots \ldots \ldots \ldots \ldots \ldots \ldots \ldots \ldots \ldots \ldots \ldots \ldots \ldots \ldots \ldots \ldots$ Reddish purple, late, good quality.

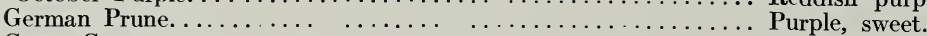

Green Gage............................. Green, sweet and rich.

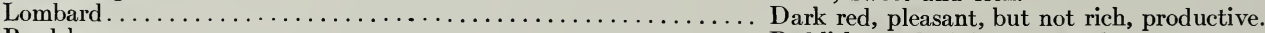

Bradshaw. . . . . . . . . .

Price, 5 -6 ft. high $\ldots \ldots \ldots \ldots \ldots \ldots \ldots \ldots \ldots \ldots \ldots \ldots \ldots \ldots$ Each, $\$ 0.50 \quad$ Per $10, \$ 4.00 \quad$ Per $100, \$ 35.00$

\section{QUINCE}

Champion and Orange........................ Yellow, good quality, long keeping.

Price, 3-5 ft. high......................... Each, $\$ 0.50 \quad$ Per $10, \$ 4.00$

\section{GRAPES}

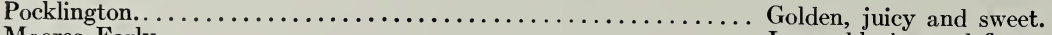

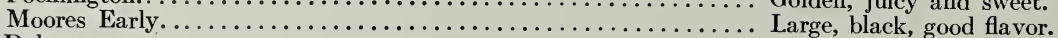

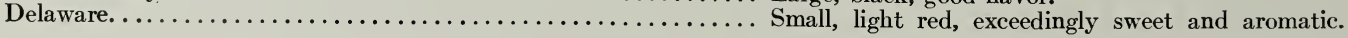




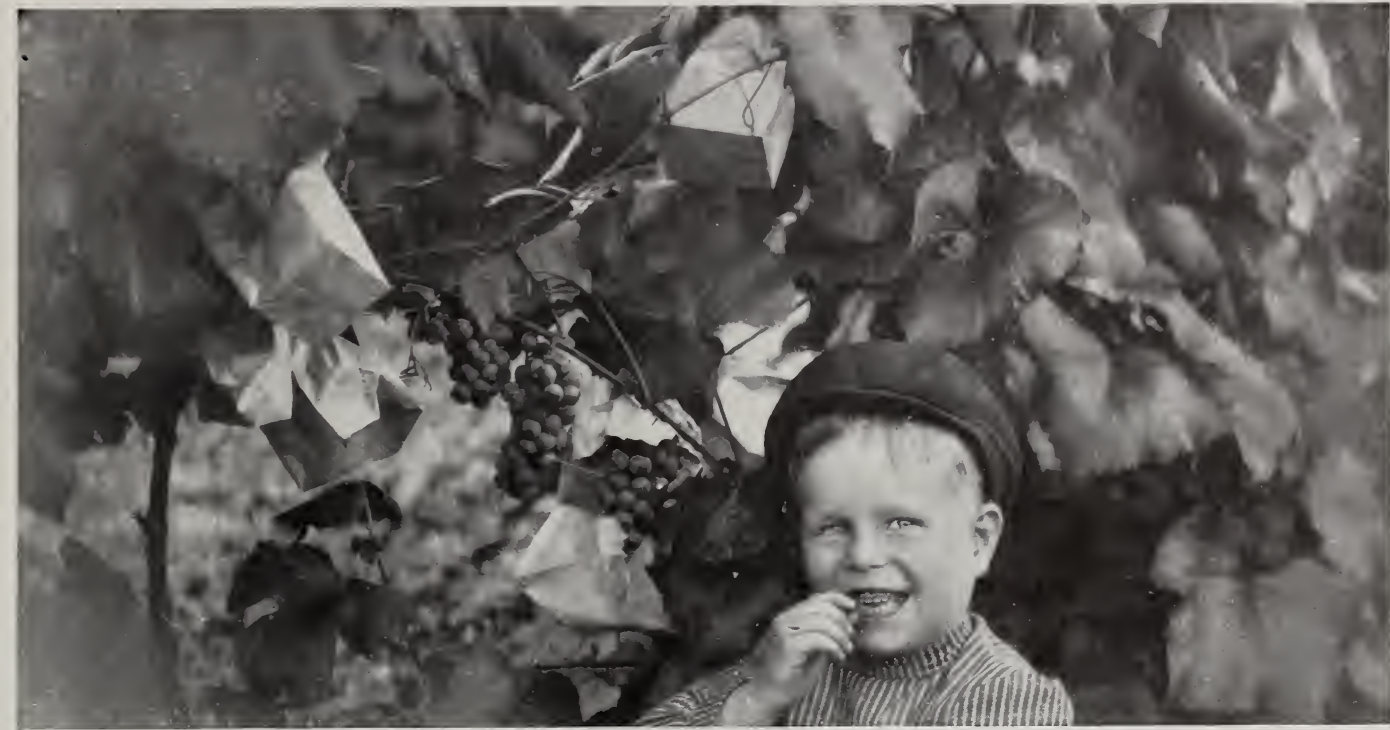

Opening a prize package. Hardly a prize package either, for the contents are sure to be good and useful. Bags are a protection from insects and birds.

\section{GRAPES - Continued.}

Niagara $\ldots \ldots \ldots \ldots \ldots \ldots \ldots \ldots \ldots \ldots \ldots \ldots \ldots \ldots \ldots \ldots \ldots \ldots \ldots \ldots \ldots \ldots \ldots \ldots \ldots$, Large, pale yellow, sweet, vigorous, and productive.

Worden. . . . . . . . . . . . .

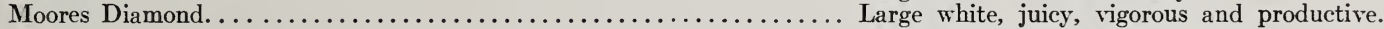

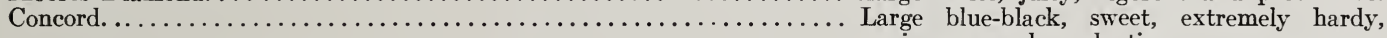
vigorous and productive.

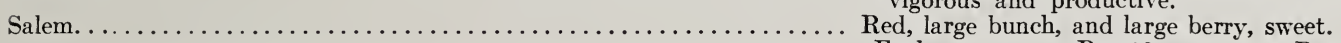

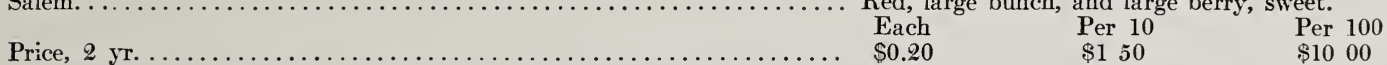

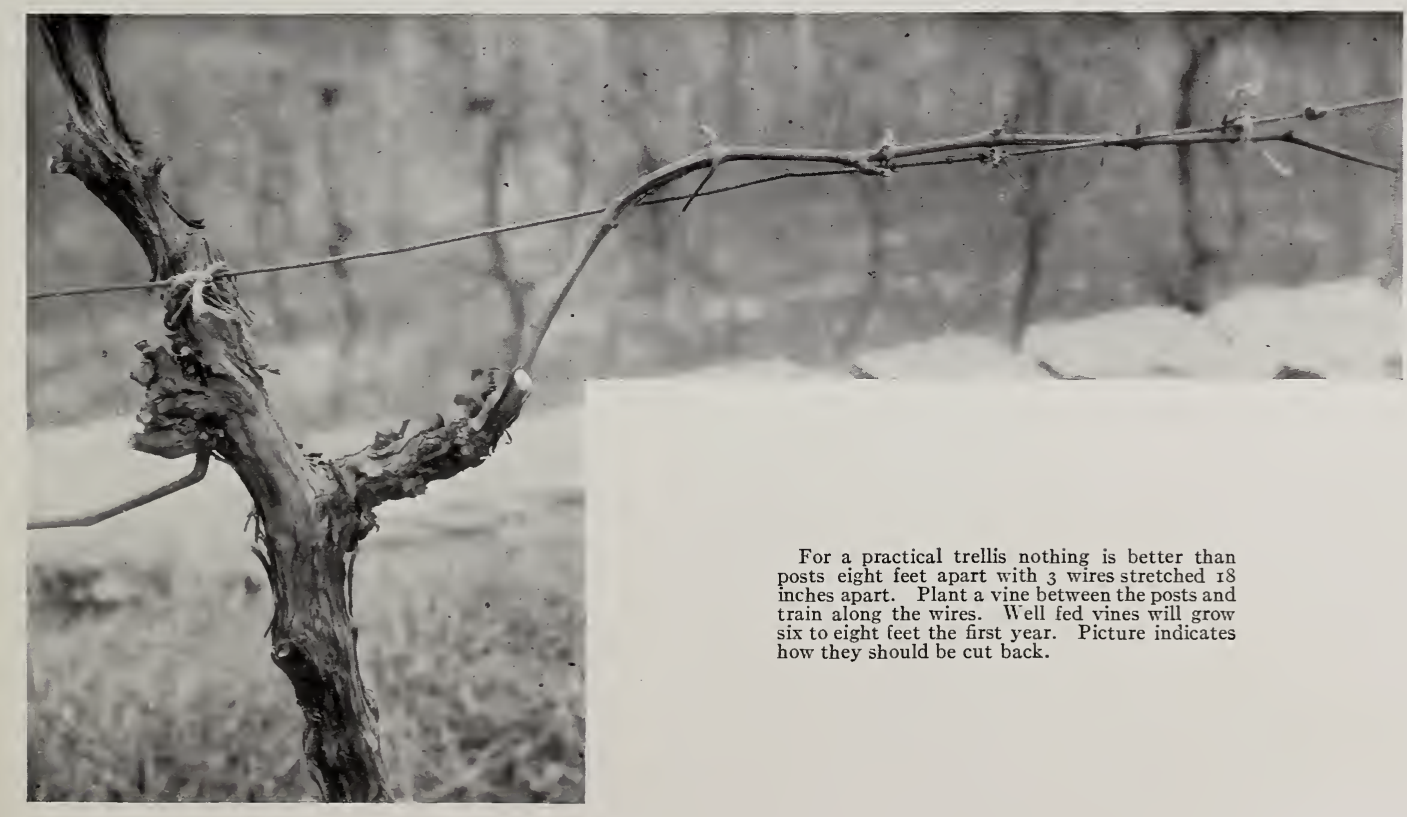




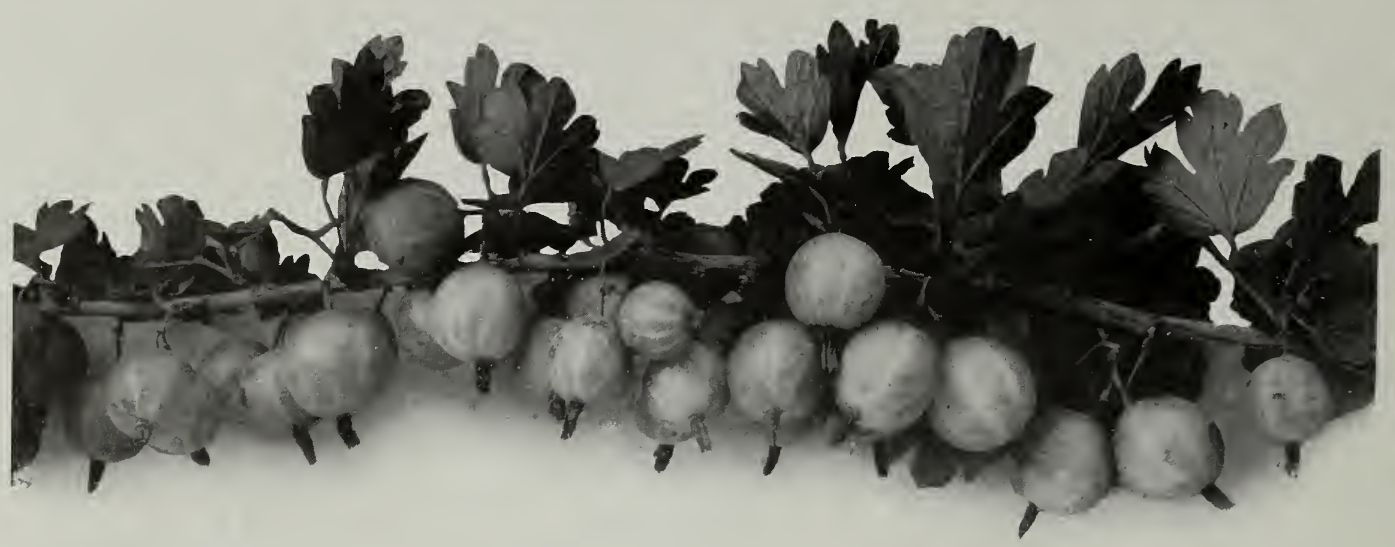

Gooseberries. Large and regular crops of gooseberries with ordinary care.

\section{Cherries}

There is a very general hunger for cherries. They are easy to grow. The principal trouble is the birds. If you plant several trees the birds will leave you some. The late varieties like Downers Late Red ripen the same time as the mazzard cherries which grow wild and the birds do not trouble them so much.

When planted cherries should be cut back more severely than apples or pears.

The Early Richmond, Montmorency and Morrello are the sour pie cherries, a distinct species making a smaller tree. Most of the others are commonly known as Ox-heart cherries.

Governor Wood........... Large, heart-shaped, yellow marked with red; sweet, juicy.

Coe's Transparent......... Medium size; amber color, with a red cheek; sweet. Ripens early.

Black Tartarian.......... Stands preeminent amongst the varieties for family use. The flavor is sweet and the quality is of the best. Fruit very large, nearly black.

Downer's Late Red........ Medium size; red and amber. This variety is late and the fruit hangs on the tree after it is ripe without decaying.

Rockport. .............. Large; clear red, shaded with amber; Ripens early.

Yellow Spanish.......... Very large, often an inch in diameter; waxen yellow, with a light red cheek; flesh firm, and of fine, rich flavor.

Napoleon............. Very large, heart-shaped; pale yellow, shaded with deep red; Ripens after midseason.

Windsor.............. Large; mottled red; very firm and juicy of good quality.

Mercer.............. A very dark red cherry; productive and early.

Schmidt's. .
May Duke.

The largest of all the black Bigarreau Cherries.

Large, round; red, changing to nearly black when ripe. Flesh very iuicy and melting; acid. Quite early.

Early Richmond. ......... (English Pie Cherry).

Montmorency............ Large; bright red; moderately sour. A good bearer which fruits young.

Morello (English Morello).... Dark red. Flavor a rich acid, making it desirable only for cooking.

Price

$5-6 \mathrm{ft}$. high.

Per 10 Per 100

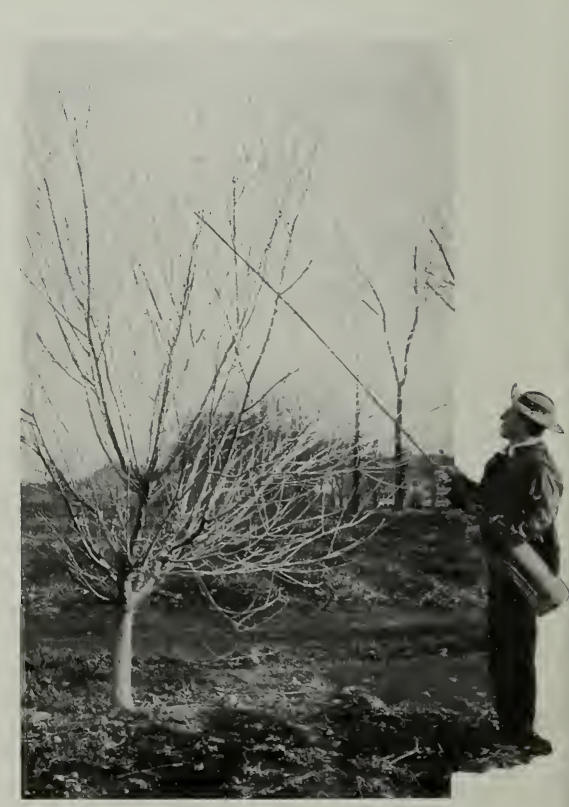

SPRAYING. Ten dollars for a spraying outfit will probably be as good an investment as you ever made. It means more and better fruit. 
FRUITS - Continued

\section{GOOSEBERRIES}

They thrive in any garden soil, and are very satisfactory for home use.

Downing. Medium, pale green, productive.

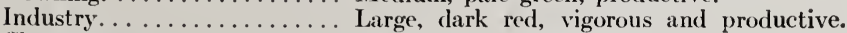

Chautauqua............ Large, sweet, prolific.

Price $. . \ldots \ldots \ldots \ldots . \quad$ Each, $\$ 025 \quad$ Per $10, \$ 200 \quad$ Per 100, $\$ 1500$

\section{CURRANTS}

Easily grown and reliable. Keep all wood over two years cut out. The currant worm is easily controlled by hellebore powder.

Cherry. . . . . . . . . . . . Dark red, acid, fine for jelly.

Fays Prolific.............. Red, long bunch of large fruit.

White Grape............. White, excellent, sweet.

Black Naples............ Black, small, musky, good for jams.

Price $\ldots \ldots \ldots \ldots \ldots \ldots$ Each, $\$ 015$ Per 10, $\$ 100$ Per 100, $\$ 750$

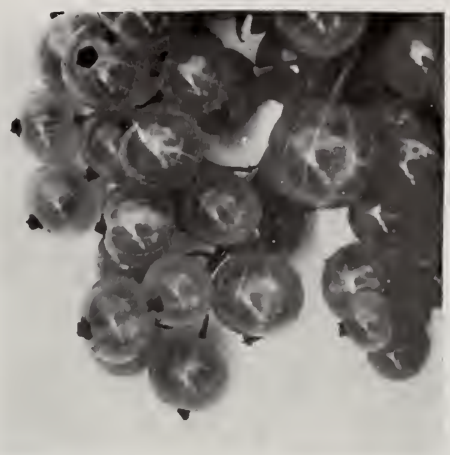

Currants. If you plant currants in the fall you can usually look for a little fruit the next summe

\section{MISCELLANEOUS}

Raspberries. .

Each Per $10 \quad$ Per 100

Blackberries.

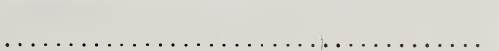

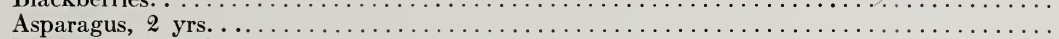

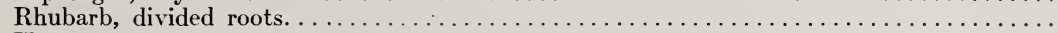

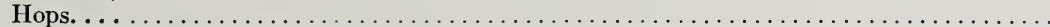

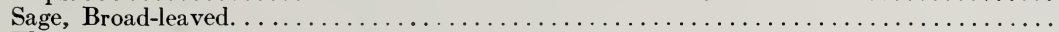

Thyme.

Horse-Radish.

$\$ \quad 8$
8

20
25
25
25
15

$\$ 50$

50

15

150

150

200

200

100

100

\section{Tubs and Pots}

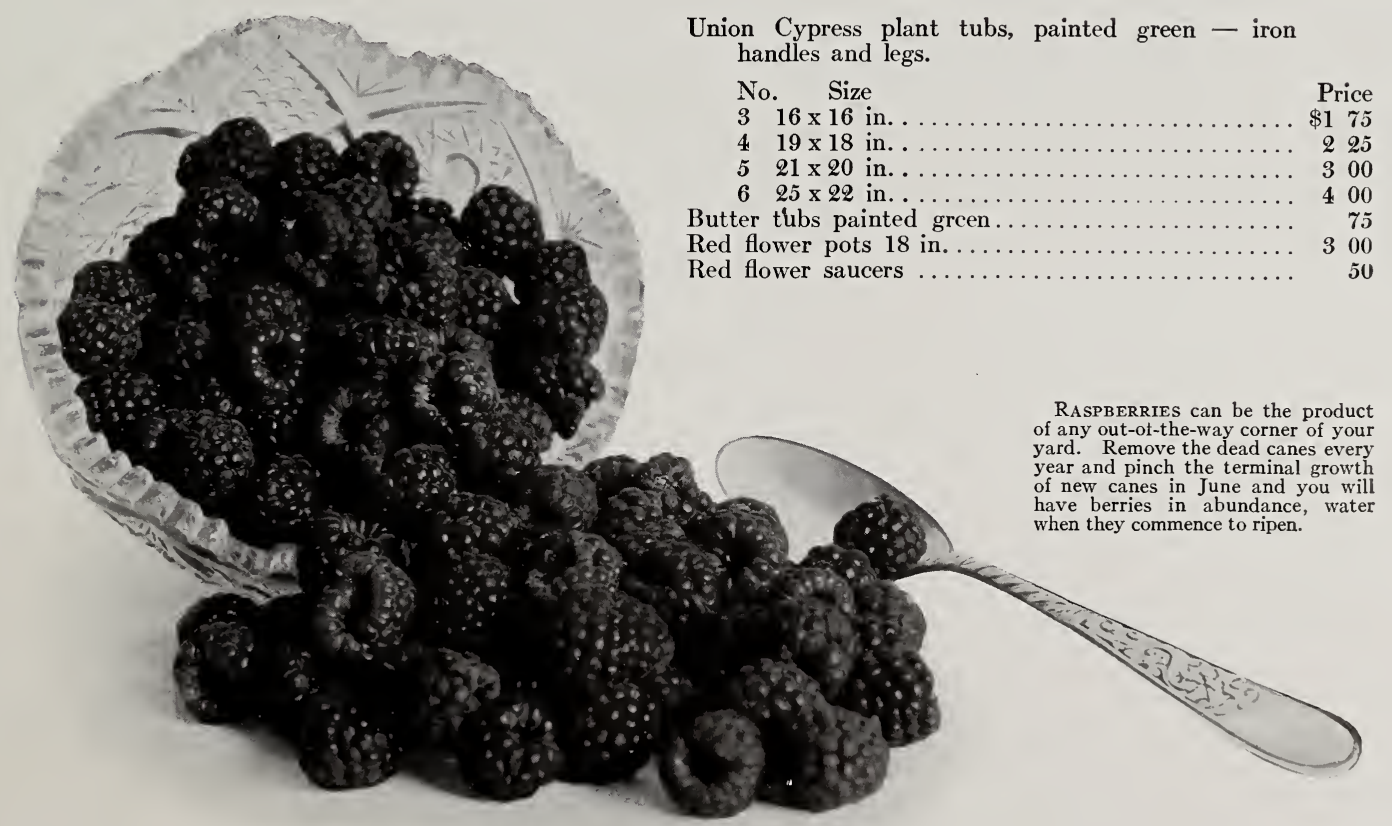




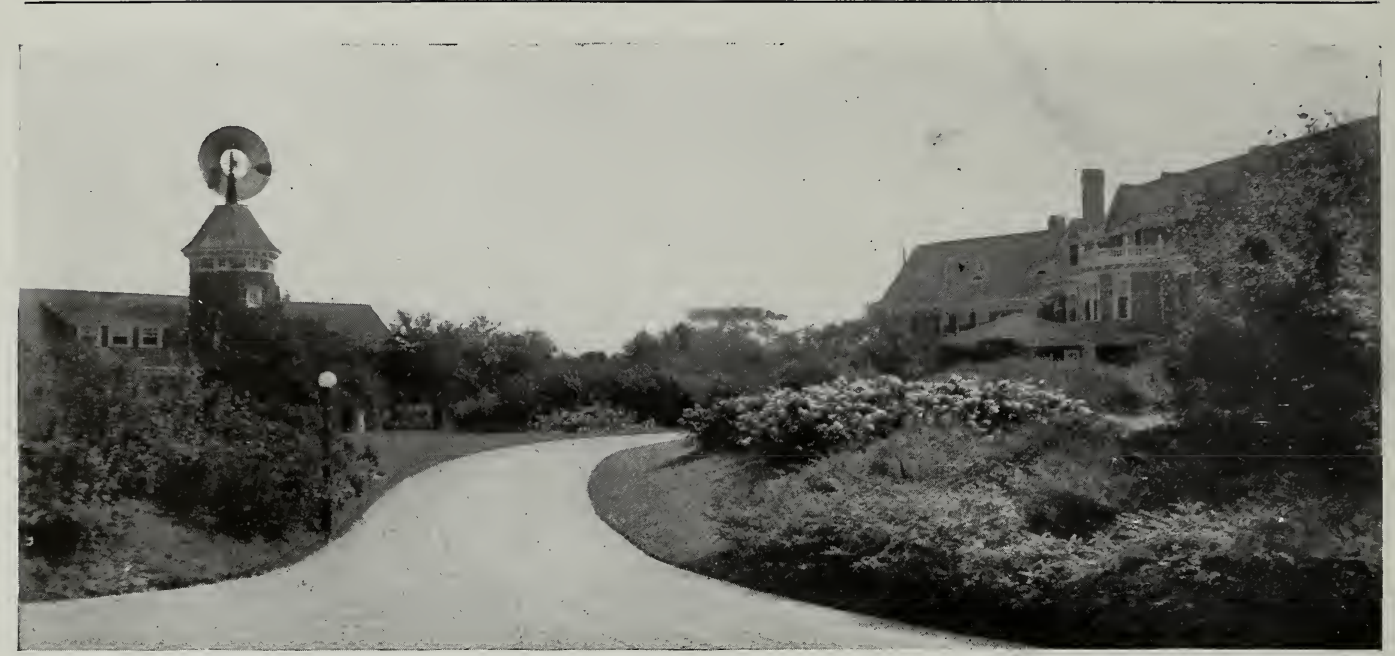

Automobile collisions around sharp curves will be few, if planting is kept low. Barberry is excellent. So is Indian Currant, Stephanandra, Rosa Rugosa, Mugho Pine, Common Juniper, and Yew. Where terraces or banks are necessary, use Honeysuckle or Trailing Roses.

\section{Some Insects and Fungus to Expect on Long Island, and How to Overcome Them.}

SAN Jose ScAle on fruit trees, currants, double-flowering fruits, and Japanese quince. Spray with lime-sulphur solution or scalecide when dormant, perferably both in November and during the winter. Codurng Moth - a worm in apple, pear and quince. Spray with arsenate of lead and Bordeaux mixture immediately after the blossoms fall, and ten days later. Currant Worm. Hellebore, dry or sprinkled on with water. Tent Caterpillar. Burn with kerosene torch. Grape Rot and Mildew. Bordeaux mixture when the buds first swell and at intervals later. BRown Rot on peach and plum. Summer spraying with lime and sulphur. Apple Maggot, or Railroad Worm. Destroy all infested fruit. Cucumber, Muskmelon, and Celery. Spray every ten days with Bordeaux mixture. Rose Aphis AND Lear Hopper. Spray with kerosene emulsion or tobacco-water. The Fall Web-Worm. Webs may be cut off, or the trees sprayed with arsenate of lead. Rhododendron Lace-Wing Fly, see page 57. Elm-Leaf Beetle, see page 8. Hickory Borer, see page 95. Chestnut Bark Disease, see page 95. Apple and Peach Borer, see page 87. The page references are to "Trees for Long Island," our descriptive catalogue.

See Annual Report of New York State Entomologist, Albany, for locust leaf miner, which is browning the foliage, and can be controlled by spraying with arsenate of lead in May; two lined chestnut borer which is killing some Oak trees. The trees should be cut and burned before the beetles come out. The same remedy applies to the White Birch borer and the Hickory borer.

Before spraying, get literature. Write to the Department of Agriculture, Washington, D. C., the Director of the New York State Agricultural Experiment Station, Geneva, N. Y.; and the Cornell College of Agriculture, Ithaca, N. Y.

For materials, The Grasselli Chemical Co., 60 Wall St., New York City, The Sherwin-Williams Co., 50 Church St. New York City, and Bowker Insecticide Co., Boston, Mass., B. G. Pratt Co., 50 Church St., N. Y. N. Y.

For pumps, The Deming Co., Salem, Ohio; E. C. Brown Co., Rochester, N. Y.; Field Force Pump Co., Lockport 


\section{How to Plant and Care for a Tree}

Srze of the HoLe. Dig the hole the full width of the roots. Do not bend them around. The tendency is to dig too dcep. Dig deeper in the centre for the central roots and keep the side roots from 4 to 12 inches below the surface.

Goon Sort. If good soil is needed, $\operatorname{dig} 1 \frac{1}{2}$ to 2 feet deep and as much wider as you wish, and fill in with good soil before placing the tree.

Trimming. Cut back severely; you will get a bigger tree. A general rule is to cut the previous year's shoots to one to three buds and thin out the balance to onehalf. With Oaks and Beeches, cut still closer, cutting off the branches $\frac{3}{8}$ to $\frac{1}{2}$ inch in diameter, but leaving some big buds. With shrubs, take out the oldest branches and leave the young graceful shoots.

Planting. Set the tree in the hole the same depth as it was before. Shovel mellow earth around the centre and pack it between the roots with a packing stick. Spread out the side roots, cover with earth and trample.

WATERING. Water helps to work the soil between the roots. Watering is not necessary, however, in autumn and early spring, as there are always rains enough. In the late spring, watering is very advantageous, especially if the buds are starting.

MANuRE. "Should manure be put in the hole?" is often asked. Not unless it is rotted. Mix it with the soil. Fresh manure near the roots may rot them. The best way is to put the manure on the top. Nature keeps a layer of decaying leaves 4 inches deep the year round. Do the same with manure. If the manure is unsightly, cover it with soil.

Commercial fertilizer, bone-meal, wood-ashes and nitrate of soda are useful, and small quantities may be applied once a year or oftener.

Care During Summer. Keep the surface cultivated 3 inches deep once in two weeks, the same as a cornfield. Eighty per cent. of the planters fail to get the best results because they neglect this point. They deceive themselves. They keep a little circle, perhaps half the width of the roots, scraped bare of weeds and grass, but the ground is hard, and not hoed 3 inches deep and loose. The hard ground allows the moisture to dry out. The closely shaven lawn does the same.

If the trecs fail to start full growth by June, they can be cut back more severely, but first examine the soil and see that it is damp and mellow.

Summer Watering. should be looked after once in two weeks. If needed, give at least 1 inch of water. Next day, stir the earth 3 inches deep, to prevent it from baking and drying out again.

HeELing IN. This means to plant temporarily. Pack the earth between the roots and, if they are to stay several days and the soil is dry, give plenty of water.

\section{APPROXIMATE SIZES OF HOLES}

\section{DECIDUOUS TREES}

\begin{tabular}{|c|c|c|c|c|c|}
\hline $\begin{array}{l}\text { Diam. of } \\
\text { trunk }\end{array}$ & $\begin{array}{l}\text { Spread of } \\
\text { branches }\end{array}$ & $\begin{array}{l}\text { Spread of } \\
\text { roots }\end{array}$ & $\underset{\text { hole }}{\text { Diam. of }}$ & $\begin{array}{l}\text { Depth of } \\
\text { centre of } \\
\text { hole }\end{array}$ & $\begin{array}{l}\text { Depth } \\
\text { at side }\end{array}$ \\
\hline 2 in. & $5 \mathrm{ft}$. & $5 \mathrm{ft}$. & $5 \mathrm{ft}$ & 12 in. & 6 in. \\
\hline 4 in. & $8 \mathrm{ft}$. & $8 \mathrm{ft}$. & $8 \mathrm{ft}$. & $15 \mathrm{in}$. & 6 in. \\
\hline $6 \mathrm{in.}$ & $12 \mathrm{ft}$. & $12 \mathrm{ft}$. & $12 \mathrm{ft}$. & 15 in. & 6 in. \\
\hline 8 in. & $16 \mathrm{ft}$. & $16 \mathrm{ft}$. & $16 \mathrm{ft}$. & 15 in. & 6 in. \\
\hline $10 \mathrm{in}$. & $22 \mathrm{ft}$. & $22 \mathrm{ft}$ : & $22 \mathrm{ft}$. & 18 in. & 6 in. \\
\hline 14 in. & $30 \mathrm{ft}$. & $30 \mathrm{ft}$. & $30 \mathrm{ft}$. & $18 \mathrm{in.}$ & 6 in. \\
\hline 18 in. & $35 \mathrm{ft}$. & $35 \mathrm{ft}$. & $35 \mathrm{ft}$. & $20 \mathrm{in.}$ & 8 in. \\
\hline 22 in. & $40 \mathrm{ft}$. & $35 \mathrm{ft}$. & $35 \mathrm{ft}$. & 20 in. & 8 in. \\
\hline
\end{tabular}

\section{EVERGREENS}

$\begin{array}{ccccr}\begin{array}{c}\text { Height } \\ \text { of tree }\end{array} & \begin{array}{c}\text { Spread of } \\ \text { branches }\end{array} & \begin{array}{c}\text { Diam. of } \\ \text { ball }\end{array} & \begin{array}{c}\text { Diam. of } \\ \text { hole }\end{array} & \begin{array}{r}\text { Depth of } \\ \text { centre of } \\ \text { hole }\end{array} \\ 5 \mathrm{ft} . & 2 \mathrm{ft} . & -1 \frac{1}{2} \mathrm{ft} . & -3 \mathrm{ft} . & 15 \mathrm{in} . \\ 8 \mathrm{ft} . & 5 \mathrm{ft} . & -3 \mathrm{ft} . & 3-5 \mathrm{ft} . & 18 \mathrm{in} . \\ 10 \mathrm{ft} . & 6 \mathrm{ft} . & 3-4 \frac{1}{2} \mathrm{ft} . & 4-6 \mathrm{ft} . & 20 \mathrm{in} . \\ 14 \mathrm{ft} . & 8 \mathrm{ft} . & 4-5 \mathrm{ft} . & 5 \frac{1}{2}-8 \mathrm{ft} . & 20 \mathrm{in} . \\ 18 \mathrm{ft} . & 10 \mathrm{ft} . & 4 \frac{1}{2}-6 \mathrm{ft} . & 6-10 \mathrm{ft} . & 20 \mathrm{in} . \\ 22 \mathrm{ft} . & 12 \mathrm{ft} . & 5-7 \mathrm{ft.} & 7-11 \mathrm{ft} . & 20 \mathrm{in} .\end{array}$

Cedars require holes of the narrowest diameter

\section{Certifícate of Inngection of JRursery Stock}

This is to certify, that the stock in the nursery of Isaac Hicks \& Son, Westbury, County of Nassau, State of New York, was duly examined in compliance with the provisions of section 305 of the Agricultural Law, and was found to be apparently free from any contagious or infectious disease or diseases, or the San Jose Scale or other dangerously injurious insect pest or pests. This certificate expires September 1, 1913.

\section{CALVIN J. HUSON,}

Dated, Albany, N. Y., September 3, 1912.

Commissioner of Agriculture. 


\section{NOW IS THE TIME TO}

CONSIDER the planting problems you might just as well dispose of as not.

CONSULT us if you wish, as to varieties appropriate for your various purposes and soil.

CONCLUDE to visit our nurseries and make your order and it will have immediate attention, or phone us if you wish.

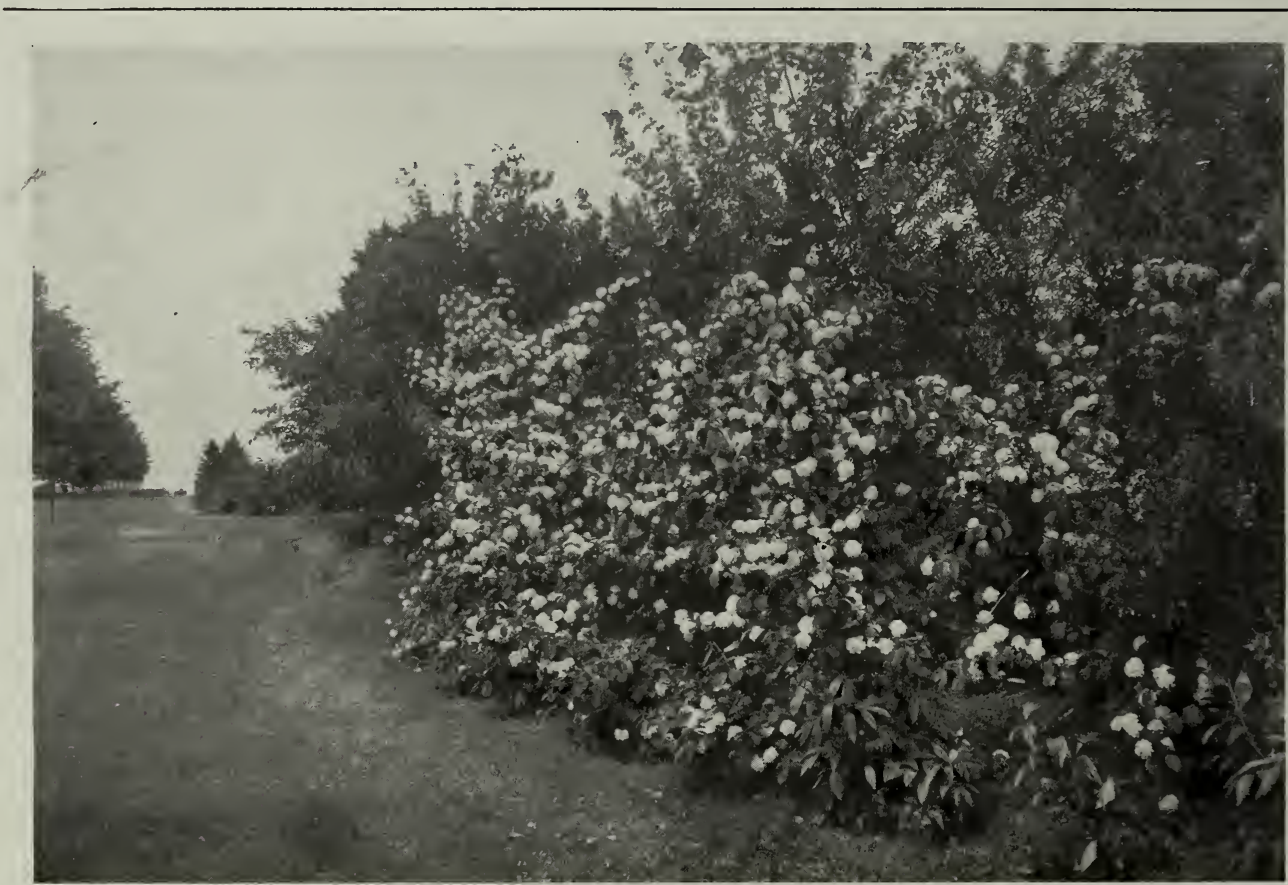

HICKS NURSERIES

WESTBURY,

NASSAU COUNTY, LONG ISLAND, NEW YORK

Telephone 68 Westbury

YOU SHOULD HAVE OUR DESCRIPTIVE CATALOGUE ON FILE AND OUR FULL PRICE LIST, TOGETHER WITH OUR EVERGREEN EDITIONS. 